Article

\title{
Mitigating Global Warming Potential and Greenhouse Gas Intensities by Applying Composted Manure in Cornfield: A 3-Year Field Study in an Andosol Soil
}

\author{
Ikabongo Mukumbuta *, Mariko Shimizu and Ryusuke Hatano \\ Soil Science Laboratory, Hokkaido University, Kita 9 Nishi 9, Kita-ku, Sapporo, Hokkaido 060-8589, Japan; \\ shimizum23@gmail.com (M.S.); hatano@chem.agr.hokudai.ac.jp (R.H.) \\ * Correspondence: ikabongo1@gmail.com; Tel.: +81-011-706-2503 \\ Academic Editor: Les Copeland
}

Received: 28 November 2016; Accepted: 7 February 2017; Published: 13 February 2017

\begin{abstract}
A 3-year study was conducted in cornfield to evaluate how composted cattle manure application affects net global warming potential (GWP; the sum of nitrous oxide $\left(\mathrm{N}_{2} \mathrm{O}\right)$ and methane $\left(\mathrm{CH}_{4}\right)$ minus net ecosystem carbon balance (NECB)) and greenhouse gas intensity (GHGI; net GWP per unit of plant biomass yield). In the first experiment, conducted from 2010 to 2012, five fertilization strategies that included an unfertilized control plot, inorganic fertilizer-only plot, two plots with inorganic fertilizer plus composted cattle manure, and composted cattle manure-only plot were established. In the second experiment composted cattle manure was applied in autumn 2012 and the field was subdivided into three plots in spring 2013, with one plot receiving additional composted cattle manure, the second plot received additional inorganic fertilizer and the third plot did not receive any additional fertilization. Fluxes of $\mathrm{N}_{2} \mathrm{O}, \mathrm{CH}_{4}$ and $\mathrm{CO}_{2}$ were measured using the static closed chamber method. NECB was calculated as carbon $(C)$ inputs minus $C$ output (where a negative value indicates net $C$ loss). In experiment 1 , manure application significantly increased NECB and reduced net GWP by more than 30\% in each of the three years of the study. GHGI in the manure-amended plots was lower than in other plots, except in 2012 when the manure-only plot had higher GHGI than fertilizer-only plot. Application of inorganic fertilizer alone increased GWP by 5\% and 20\% in 2010 and 2011, but showed a 30\% reduction in 2012 relative to the unfertilized control plot. However, due to higher net primary production (NPP), fertilizer-only plot had lower GHGI compared to the control. Application of inorganic fertilizer together with manure showed the greatest potential to reduce GWP and GHGI, while increasing NPP and NECB. In experiment 2, additional manure or inorganic fertilizer application in spring increased NPP by a similar amount, but additional manure application also increased NECB, and decreased GWP and GHGI. Manure application, as a partial substitute or supplemental fertilizer, shows potential to mitigate GWP and GHGI.
\end{abstract}

Keywords: global warming potential; greenhouse gas intensity; soil carbon; manure; cornfield

\section{Introduction}

Warming of the global climate is undoubtedly caused by the increase in greenhouse gas (GHG) concentrations in the atmosphere [1]. Carbon dioxide $\left(\mathrm{CO}_{2}\right)$, methane $\left(\mathrm{CH}_{4}\right)$ and nitrous oxide $\left(\mathrm{N}_{2} \mathrm{O}\right)$ are released from soils into the atmosphere due to microbial processes that break down organic and inorganic materials added to and existent in soils [2-4]. Globally $\mathrm{CO}_{2}$ has the greatest radiative forcing among the three GHGs [1]. The agriculture sector has low net $\mathrm{CO}_{2}$ emissions relative to other sectors but has one of the largest potentials for mitigation through soil carbon (C) sequestration [3]. Soil $\mathrm{CH}_{4}$ flux in aerobic upland soils is a result of the balance between methanogenesis and $\mathrm{CH}_{4}$ consumption [5]. 
Changes in abiotic factors and land management practices can significantly alter the balance between $\mathrm{CH}_{4}$ production and consumption in the soil $[6,7]$. Soil $\mathrm{N}_{2} \mathrm{O}$ is predominantly produced by nitrification and denitrification processes [8], and is influenced by the availability of soil nitrogen (N), soil C, temperature, $\mathrm{pH}$ and soil moisture content in the soil [9-14]. Intensification of agricultural production and the use of inorganic and organic fertilizers (such as animal manure) are the major cause of the increased GHG emissions from agriculture $[1,3,15]$. With the need to meet the growing demand of food due to growing global population, increase in the use of fertilizers (both organic and inorganic) is inevitable, especially in developing countries [16]. On the other hand, reducing GHG emissions is of great concern globally [1]. Management practices that mitigate GHG emissions while enhancing crop productivity are therefore essential [17-19].

A number of studies have been done to evaluate how management practices, such as tillage, manure and fertilizer application, affect GHG emissions [20-26]. Adequate fertilization and manure application have been reported to increase soil organic carbon (SOC) through increased biomass production and through direct $\mathrm{C}$ input from manure and residue retention in soils [27-32]. On the other hand, both manure and fertilizer application can increase $\mathrm{N}_{2} \mathrm{O}$ and $\mathrm{CH}_{4}$ emissions [33-35] and partly offset the benefits of increased SOC sequestration. Therefore, the overall change in GHG emissions and $\mathrm{SOC}$ sequestration should be evaluated when assessing the benefits of any management practice.

To easily compare the effects $\mathrm{N}_{2} \mathrm{O}, \mathrm{CH}_{4}$ and $\mathrm{CO}_{2}$ emitted in the atmosphere, $\mathrm{CO}_{2}$-equivalents (the radiative forcing relative to $\mathrm{CO}_{2}$ over a 100-year period) are widely used. Net global warming potential (GWP), the sum of $\mathrm{CO}_{2}$-equivalents of $\mathrm{N}_{2} \mathrm{O}, \mathrm{CH}_{4}$ and $\mathrm{CO}_{2}$, is a good measure of the overall exchange of GHGs in a system [36]. Agricultural ecosystems do not only emit $\mathrm{CO}_{2}$ but also uptake (remove) $\mathrm{CO}_{2}$ from the atmosphere through plant photosynthesis. Some of the $\mathrm{CO}_{2}$ removed through photosynthesis may end up in the soil as SOC. Some researchers have therefore used change in SOC; rather direct $\mathrm{CO}_{2}$, when calculating net GWP from agricultural ecosystems. However, direct measurement of SOC content in most cases only detects changes in SOC over 5-10 years time scales (or even longer) and is not sensitive enough to account for small seasonal and annual changes [37]. Net ecosystem C balance (NECB) has been proposed to more accurately account for changes in $C$ accumulation in an ecosystem $[37,38]$. Despite having some limitations such as being influenced by annual climatic variations [38], by measuring the $\mathrm{C}$ input, $\mathrm{C}$ output and net $\mathrm{CO}_{2}$ flux from an ecosystem to the atmosphere, NECB is one of the best methods for measuring $\mathrm{C}$ changes in cropland over shorter periods such as annually [39]. Therefore, NECB, in addition to $\mathrm{N}_{2} \mathrm{O}$ and $\mathrm{CH}_{4}$, is used to calculate net GWP in this study.

Since the ultimate goal should be to reduce GHG emissions while being able to increase crop productivity, net GWP must be compared to the crop yield. Greenhouse gas intensity (GHGI), which is calculated by dividing GWP by the crop yield [40], can give a good idea of whether a given management practice can increase productivity without increasing GHG emissions. While many studies have reported the effect of inorganic fertilizer and manure application on $\mathrm{CO}_{2}, \mathrm{CH}_{4}$ and $\mathrm{N}_{2} \mathrm{O}$ emissions, very few have evaluated their effect on GWP and GHGI.

The amount as well as the timing of manure and fertilizer application influences both crop productivity and GHG emissions. The readily availability of inorganic fertilizer $\mathrm{N}$ makes it easy to be taken up by plants but also to be easily transformed by microbial processes into $\mathrm{N}_{2} \mathrm{O}$ and other gaseous forms. On the other hand, when composted, animal manure is a slow-release fertilizer and it is widely considered to be a good substitute for inorganic fertilizer [39]. However, low nutrient content of composted manures, compared to inorganic fertilizers, could lead to reduced crop yields. It is therefore important to evaluate the ability of manures to maintain yields if they are to be a real alternative to inorganic fertilizers.

We hypothesized that (1) manure application can increase $C$ sequestration and offset increase in non- $\mathrm{CO}_{2}$ GHGs; (2) applying manure twice (in autumn and spring) can achieve the same amount of crop productivity compared to conventional inorganic fertilizer (in spring) without increasing $\mathrm{N}_{2} \mathrm{O}$ emissions. To test our hypotheses, we initiated a field experiment in 2010 to gain insights into the 
effects of manure and inorganic fertilizer on GHG emissions, GWP and GHGI in a cornfield. We also explore the major factors driving GHG fluxes in the soil.

\section{Materials and Methods}

\subsection{Site Description}

Field monitoring was done at an experimental farm of the Field Science Centre for Northern Biosphere of Hokkaido University in Shin-Hidaka city, Southern Hokkaido, Japan ( $\left.42^{\circ} 26^{\prime} \mathrm{N}, 142^{\circ} 29^{\prime} \mathrm{E}\right)$. The site experiences cold winters and relatively cool summers with average annual air temperature and precipitation of $8.1{ }^{\circ} \mathrm{C}$ and $1252 \mathrm{~mm}$, respectively. In winter, the soil is covered with snow and frozen from December to March. The soil is derived from volcanic ash and classified as a Mollic Andosol (IUSS Working Group WRB 2006).

Before initiation of this study, the field (2-ha) had been managed as a grassland for more than 30 years with reed canary grass (Phalaris arundinacea L.) as the dominant species. From 2005 half of the field had been applied with inorganic fertilizer and the other half with composted cattle manure with supplemental inorganic fertilizer. Herbicide was applied in September 2009 to kill the grass and the field was ploughed in December the same year.

\subsection{Experimental Set Up}

Three of the experimental plots used in this study were established in 2005 as inorganic fertilizer plus composted cattle manure (MF1), inorganic fertilizer-only (F) and unfertilized control plot (CT). In 2010 half of previous inorganic fertilizer plot was applied with composted manure, establishing a new inorganic fertilizer plot plus composted cattle manure (MF2). Part of the MF1 plot did not receive supplemental inorganic fertilizer from 2011 onwards, and hence called the composted cattle manure-only plot $(\mathrm{M})$. These five plots were replicated 4 times in a complete randomized design with each plot measuring $5 \mathrm{~m} \times 5 \mathrm{~m}$ in size and used in experiment 1 . In experiment 2 , small plots (described below) were set up in the fertilizer-only part of the field.

\subsubsection{Experiment 1: Effect of Manure and Inorganic Fertilizer}

Field measurements were conducted from October 2009 to October 2012 in CT, F, MF1, MF2 and M plots. Composted cattle manure was applied at the end of October in 2009, 2010 and 2011 and the field ploughed ( $30 \mathrm{~cm}$ depth) within two to three weeks after manure application. The average amount of manure applied in each year was $40 \mathrm{Mg}$ fresh matter representing $390 \mathrm{~kg}$ total $\mathrm{N}$ and $6.8 \mathrm{Mg}$ total $\mathrm{C}$ per hectare (Table S1). The manure was composted beef cattle manure with bedding litter (bark). In early May 2010, 2011 and 2012, the field was disc harrowed, after which maize was seeded and inorganic fertilizer $\left(104 \mathrm{~kg} \mathrm{~N}\right.$ as $\mathrm{NH}_{4} \mathrm{PO}_{3}, 139 \mathrm{~kg}$ phosphorous $(\mathrm{P})$ as $\mathrm{P}_{2} \mathrm{O}_{5}$ and $77 \mathrm{~kg}$ potassium $(\mathrm{K})$ as $\mathrm{K}_{2} \mathrm{O}$ per hectare) applied on 18 May in 2010 and 2011 and on 21 May in 2012 in the respective plots. Lime was applied in all the treatment plots at the rate of $300 \mathrm{~kg} \mathrm{CaCO}_{3} \mathrm{ha}^{-1}$.

\subsubsection{Experiment 2: Effect of Additional Spring Manure Application}

A second experiment was conducted for one year from October 2012 to September 2013. In this experiment, three plots were set up to assess the effect of additional manure application in spring season on plant growth and net GHG emissions. The treatments were autumn composted cattle manure application (M1), autumn composted cattle manure application and additional spring inorganic fertilizer application (MF) and autumn composted cattle manure plus additional spring manure application (MM). Autumn manure application was done in November 2012 (40 Mg fresh matter: $450 \mathrm{~kg} \mathrm{~N}$ and $7.3 \mathrm{Mg}$ C per hectare). In May 2013 (spring), additional $29 \mathrm{Mg}$ fresh manure was applied in the MM plot (300 kg N and $5 \mathrm{Mg} C$ per hectare), and inorganic fertilizer (104 kg N, $139 \mathrm{~kg} \mathrm{P}$ and $77 \mathrm{~kg} \mathrm{~K}$ per hectare) was applied in the MF plot (Table S2). Lime at the rate of $300 \mathrm{~kg} \mathrm{CaCO}_{3}$ was applied in all the plots. 


\subsection{Measurement of Soil and Climatic Variables}

Soil samples from the top $5 \mathrm{~cm}$ depth were collected and sieved ( $2 \mathrm{~mm}$ mesh) on each sampling day (every 1-2 weeks) except in winter when we did not collect any soil samples due to freezing conditions. The soils were then extracted with deionized water for nitrate $\left(\mathrm{NO}_{3}{ }^{-}\right), \mathrm{pH}$ and water extractable organic $\mathrm{C}$ (WEOC) measurements and with $2 \mathrm{M} \mathrm{KCl}$ solution for ammonium $\left(\mathrm{NH}_{4}{ }^{+}\right)$ measurements. The extracts were filtered through $0.2 \mu \mathrm{m}$ membrane filters and stored at $4{ }^{\circ} \mathrm{C}$ until analysis. Soil $\mathrm{NO}_{3}{ }^{-}$concentrations were analyzed by ion chromatography (Dionex QIC Analyzer; Dionex Japan, Osaka, Japan) and soil pH by using a combined electrode $\mathrm{pH}$ meter (F-8 pH meter; Horiba, Kyoto, Japan). Ammonium concentration was determined using the indophenol-blue method (UV mini 1240; Shimadzu, Kyoto, Japan). Total organic C (TOC) analyzer (TOC 5000A; Shimadzu, Japan) was used to measure WEOC.

We collected core samples at each soil sampling time for soil bulk density determination and soil moisture content was measured gravimetrically. Soil water-filled pore space was calculated from the measured gravimetric moisture content, bulk density and total porosity [41,42].

Daily precipitation data was obtained from the Sasayama Automated Meteorological Data Acquisition System (AMEDAS) station of the Japan Meteorological Agency, which is located within $1 \mathrm{~km}$ from the study site. Soil temperature $(5 \mathrm{~cm}$ depth) was measured at 30-min intervals by using permanently installed thermocouple thermometers (TR-52, T \& D, Nagano, Japan).

\section{Total Soil N and Soil C Analysis}

In 2010 and 2012, we collected soils in the F, MF1 and MF2 plots at 0-5, 5-15 and 15-30 cm soil depth to measure total soil $\mathrm{N}$ and SOC stored each soil layer. These samples were collected at the end of the growing season. The samples were collected every $10 \mathrm{~m}$ in a grid covering the entire field resulting in at least 12 points for each plot. Total $\mathrm{N}$ and $\mathrm{C}$ were analysed using a $\mathrm{C} / \mathrm{N}$ analyzer (SUMIGRAPH NC-1000; Sumika Chemical Analysis Service, Ltd., Osaka, Japan). In 2004, prior to the initiation of the treatments, total soil $\mathrm{N}$ and SOC was measured [43] and this value was used as the reference for measuring the change in SOC. The amount of SOC stored in the soil layer was calculated based on the equation below $[19,44]$ :

$$
\text { Total C storage }\left(\mathrm{Mg} \mathrm{Cha}^{-1}\right)=\mathrm{SOC} \times \mathrm{BD} \times \mathrm{H}
$$

where SOC is the organic $\mathrm{C}$ content $(\%), \mathrm{BD}$ is soil bulk density $\left(\mathrm{Mg} \cdot \mathrm{m}^{-3}\right)$ and $\mathrm{H}$ is the thickness of the soil layer (m).

The rate of SOC accumulation $\left(\mathrm{Mg} \mathrm{C} \mathrm{ha}^{-1} \cdot \mathrm{year}^{-1}\right)$ in the soil was calculated as the difference between the total C storage per hectare in 2010 or 2012 and the reference year (2004) as mentioned above and divided by the number of years.

\subsection{Greenhouse Gas Flux Measurement}

The GHGs flux measurements were conducted using the static closed chamber method at 1-2 weeks intervals from late March to late November and 3-4 weeks intervals during the winter season (December to March). Gas sampling was conducted between 8:00 a.m. and 12:00 p.m. on each measuring day to minimize the effect of diurnal temperature variation on gas fluxes.

Chambers used were made of stainless steel and were $20 \mathrm{~cm}$ in diameter and $25 \mathrm{~cm}$ in height. The cover of the chamber was made of acryl and was equipped with a sample collector and pressure-regulating bag as described by Toma and Hatano [45]. The chambers were placed onto chamber-bases, which were permanently installed into the soil to a depth of about $3 \mathrm{~cm}$. For $\mathrm{N}_{2} \mathrm{O}$ and $\mathrm{CH}_{4}$ measurements chamber bases were placed in the inter-row space and the other two in intra-row spaces of the corn plants. Chambers for $\mathrm{CO}_{2}$ flux measurements were installed in root excluded plots as described by Shimizu et al. [46], therefore the reported $\mathrm{CO}_{2}$ fluxes represent soil heterotrophic respiration. Gas samples were collected manually using a 50-mL syringe at 0 and 6 min for $\mathrm{CO}_{2}$ and 
0 and 20 min for $\mathrm{N}_{2} \mathrm{O}$ and $\mathrm{CH}_{4}$ after chamber closure [34]. 200-mL sample was then injected into pre-vacuumed Tedlar bags for $\mathrm{CO}_{2}$ measurement and 20-mL gas sample was injected into an evacuated vial bottle for $\mathrm{N}_{2} \mathrm{O}$ and $\mathrm{CH}_{4}$ analysis.

The $\mathrm{CO}_{2}$ gas concentrations were determined in the laboratory within $6 \mathrm{~h}$ after sampling using a $\mathrm{CO}_{2}$ infrared gas analyzer (ZFP9GC11, Fuji Electric, Tokyo, Japan). $\mathrm{N}_{2} \mathrm{O}$ gas concentrations were determined in the laboratory using a gas chromatograph (GC-14B; Shimadzu, Kyoto, Japan) equipped with an electron capture detector (ECD). $\mathrm{CH}_{4}$ gas concentrations were determined using a flame ionization detector equipped gas chromatograph (GC-8A; Shimadzu, Kyoto, Japan).

The following linear regression equation was used to calculate the gas flux from the soil [47]:

$$
F\left(\mathrm{mg} \cdot \mathrm{m}^{-2} \cdot \mathrm{h}^{-1}\right)=\rho \times V / A \times \Delta c / \Delta t \times[273 /(273+T)] \times \alpha
$$

where $F$ is the gas flux; $\rho$ is the density of each measured gas at standard conditions $\left(\mathrm{CO}_{2}=1.96 \times 10^{6} \mathrm{mg} \cdot \mathrm{m}^{-3}, \quad \mathrm{CH}_{4}=7.16 \times 10^{5} \mathrm{mg} \cdot \mathrm{m}^{-3}, \quad \mathrm{~N}_{2} \mathrm{O}=1.97 \times 10^{6} \mathrm{mg} \cdot \mathrm{m}^{-3}\right.$, and $\left.\mathrm{NO}=1.34 \times 10^{6} \mathrm{mg} \cdot \mathrm{m}^{-3}\right) ; V$ is the volume of the chamber $\left(\mathrm{m}^{3}\right), A$ is the surface area of the chamber $\left(\mathrm{m}^{2}\right) ; \Delta c / \Delta t\left(10^{-6} \mathrm{~m}^{3} \cdot \mathrm{m}^{-3} \cdot \mathrm{h}^{-1}\right)$ is the ratio of change in gas concentration in the chamber during the sampling time; $\mathrm{T}$ is the air temperature inside the chamber $\left({ }^{\circ} \mathrm{C}\right)$; and $\alpha$ is ratio of molar mass of $\mathrm{C}$ or $\mathrm{N}$ of the molecular weight of each respective gas $\left(\mathrm{CO}_{2}=12 / 44, \mathrm{CH}_{4}=12 / 16, \mathrm{~N}_{2} \mathrm{O}=28 / 44\right)$. Based on this equation a positive flux value indicates that gas emission from soil surface into the atmosphere occurred, while negative flux indicates gas sink from the atmosphere into the soil.

Cumulative annual emissions were calculated by linear interpolation between sampling events and numerical integration of underlying area using the trapezoid rule [48].

From the cumulative annual $\mathrm{N}_{2} \mathrm{O}$ emissions, we calculated inorganic fertilizer $\mathrm{N} \mathrm{N}_{2} \mathrm{O}$ emission factors $(\mathrm{EF})$ using the equation below:

$$
\mathrm{EF}=\mathrm{N}_{2} \mathrm{O}-\mathrm{N}(\mathrm{F} \text { plot })-\mathrm{N}_{2} \mathrm{O}-\mathrm{N}(\mathrm{CT} \text { plot }) / \mathrm{N} \text { application rate in } \mathrm{F} \text { plot }
$$

The relationship between $\mathrm{CO}_{2}$ flux and soil temperature was calculated using an exponential function (Equation (4)). We then calculated the Q10 values of soil $\mathrm{CO}_{2}$ flux using Equation (5).

$$
\begin{aligned}
\mathrm{CO}_{2} \text { flux } & =\beta_{0} \times \exp \left(\beta_{1} \times T\right) \\
\mathrm{Q} 10 & =\exp \left(10 \times \beta_{1}\right)
\end{aligned}
$$

where $T$ is the soil temperature at $5 \mathrm{~cm}$ depth, $\beta_{0}$ and $\beta_{1}$ are coefficients of the $\mathrm{CO}_{2}$ flux and temperature function.

\subsection{Estimation of NECB, GWP and GHGI}

Net ecosystem $C$ balance was calculated using the following equation $[37,39,49]$ :

$$
\begin{gathered}
\mathrm{NECB}=\mathrm{C} \text { input }-\mathrm{C} \text { output } \\
\mathrm{C} \text { input }=\text { manure } \mathrm{C}+\mathrm{NPP} \\
\mathrm{C} \text { output }=\text { Harvested } \mathrm{C}+\mathrm{RH}
\end{gathered}
$$

where manure $C$ is the total $C$ in the applied manure, NPP is net primary production (measured as total $\mathrm{C}$ in aboveground and belowground dry plant biomass), harvested $\mathrm{C}$ is the total $\mathrm{C}$ removed through the harvested plant material and $\mathrm{RH}$ is heterotrophic soil respiration (measured as the soil $\mathrm{CO}_{2}-\mathrm{C}$ from the plant excluded plots). The aboveground biomass was manually harvested by cutting the plant biomass at 8 replications $(1.5 \mathrm{~m} \times 1 \mathrm{~m}$ area). The belowground biomass was measured at 8 replications $(1.5 \mathrm{~m} \times 1 \mathrm{~m}$ area) by digging out the corn roots and manually separating the roots from the soil by sieving using a $0.5 \mathrm{~mm}$ sieve and then by washing to completely remove the soil particles and other 
debris. The plant samples were oven-dried at $70{ }^{\circ} \mathrm{C}$ for more than $72 \mathrm{~h}$ and weighed. Each dried sample was analysed for total $\mathrm{C}$ and $\mathrm{N}$ contents with a C/N analyzer (SUMIGRAPH NC-1000, Sumika Chemical Analysis Service, Ltd., Osaka, Japan).

Global warming potential (GWP) was estimated based on the following equation adopted from Zhang et al. [17]:

$$
\mathrm{GWP}=\left[E_{\mathrm{CH} 4-\mathrm{C}} \times 16 / 12 \times 25+E_{\mathrm{N} 2 \mathrm{O}-\mathrm{N}} \times 44 / 28 \times 298\right] \times 12 / 44-\mathrm{NECB}
$$

where GWP is global warming potential $\left(\mathrm{kg} \mathrm{CO}_{2}-\mathrm{C}\right.$ equivalents $\left.\mathrm{ha}^{-1} \cdot \mathrm{year}^{-1}\right), E_{\mathrm{CH} 4-\mathrm{C}}$ and $E_{\mathrm{N} 2 \mathrm{O}-\mathrm{N}}$ are the annual emission rates of $\mathrm{CH}_{4}-\mathrm{C}$ and $\mathrm{N}_{2} \mathrm{O}-\mathrm{N}\left(\mathrm{kg} \cdot \mathrm{ha}^{-1}\right.$. year $\left.{ }^{-1}\right)$. The fractions $16 / 12$ and $44 / 28$ are used to convert the mass of $\mathrm{CH}_{4}-\mathrm{C}$ to $\mathrm{CH}_{4}$ and the mass of $\mathrm{N}_{2} \mathrm{O}-\mathrm{N}$ to $\mathrm{N}_{2} \mathrm{O}$. The constants 25 and 298 are the radiative forcing constants $\left(\mathrm{CO}_{2}\right.$ equivalents) of $\mathrm{CH}_{4}$ and $\mathrm{N}_{2} \mathrm{O}$, respectively, relative to $\mathrm{CO}_{2}$ over a 100-year time horizon [1]. The fraction $12 / 44$ was used to convert $\mathrm{CO}_{2}$ equivalents to $\mathrm{CO}_{2}-\mathrm{C}$ equivalents for easy comparison of NECB contribution to GWP.

By using the above equation, we measured the direct $\mathrm{CO}_{2}$ equivalents from crop production and we did not consider indirect emissions such as those from fertilizer production and farm operations.

The corn from our study site was used for silage and therefore the GHGI was calculated as GWP divided by biomass yield:

$$
\text { GHGI }=\text { GWP } / \text { Yield }
$$

\subsection{Data Analysis}

Statistical analysis was done using STATA-13 (Stata Corporation, College Station, TX, USA). Two-way analysis of variance (ANOVA) was used to evaluate the treatment and annual differences in GHG fluxes, GWP and GHGI. Pearson's correlation test was used to test the relationship between weather and soil variables with GHG fluxes and cumulative annual emissions.

\section{Results}

\subsection{Soil and Environmental Variables}

Monthly average air temperatures ranged from $-10.7^{\circ} \mathrm{C}$ to $30.5^{\circ} \mathrm{C}$ with the lowest temperatures observed in February, while the maximum temperatures were recorded between July and September. Average air temperatures were less than $0{ }^{\circ} \mathrm{C}$ from December to March. Soil temperature followed the same trend with air temperature. The soil temperature ranged from $-4.0^{\circ} \mathrm{C}$ to $27^{\circ} \mathrm{C}$ (Figure 1a).

Average monthly precipitation ranged from 5 to $224 \mathrm{~mm}$. The driest months with lowest precipitation were from January to March and the wettest months were from July to September. Annual precipitation was 1120, 1006 and $1066 \mathrm{~mm}$ in 2010, 2011 and 2012 respectively.

Soil $\mathrm{NO}_{3}{ }^{-}$concentrations increased in May after fertilizer application and were higher in MF2, MF1 and F plots compared to CT and M plots (Figure 1b). Short-lived peaks in $\mathrm{NO}_{3}{ }^{-}$concentration were sometimes observed after manure application. Nitrate concentrations were higher in 2010 in all plots and lowest in 2012. In the unfertilized control plot, average $\mathrm{NO}_{3}{ }^{-}$concentration was $60 \mathrm{mg} \cdot \mathrm{kg}^{-1}$ in 2010 but decreased to $12 \mathrm{mg} \cdot \mathrm{kg}^{-1}$ in 2012. The high $\mathrm{NO}_{3}{ }^{-}$concentrations 2010 could have resulted from $\mathrm{N}$ mineralization, as this was the first year after the conversion from grassland to cornfield.

Annual and seasonal variations in soil $\mathrm{NH}_{4}{ }^{+}$concentrations showed a different trend from that of soil $\mathrm{NO}_{3}{ }^{-}$concentrations (Figure 1c). Ammonium concentrations were highest in 2012 and very low concentrations were observed in 2010 . Overall very high variations in $\mathrm{NH}_{4}{ }^{+}$concentration were observed with values ranging from 0 to $900 \mathrm{mg} \cdot \mathrm{N} \cdot \mathrm{kg}^{-1}$. Highest $\mathrm{NH}_{4}{ }^{+}$concentrations were observed in spring just after soil melting and after fertilization and the peaks were more pronounced in MF2 and MF1 plots. The manure amended plots also showed the highest variations in $\mathrm{NH}_{4}{ }^{+}$concentrations.

Water extractable organic C was significantly lower in 2010 and increased annually with highest concentrations found in 2012 (Figure 1d). Water extractable organic $C$ was higher in the manure-amended plots (MF1, MF2 and M) than the plots without manure application $(p<0.01)$. 
Soil $\mathrm{pH}$ varied among the different treatments and increased from 2010 to 2012 due to liming. Soil $\mathrm{pH}$ was generally lower in MF2 and F plots compared to CT, MF1 and M plots. The average annual soil $\mathrm{pH}$ ranged from 4.8-5.6, 4.7-5.5 in F and MF2 plots, and 5.2-5.7, 5.0-5.7 and 5.7-5.8 in CT, MF1 and M plots respectively.
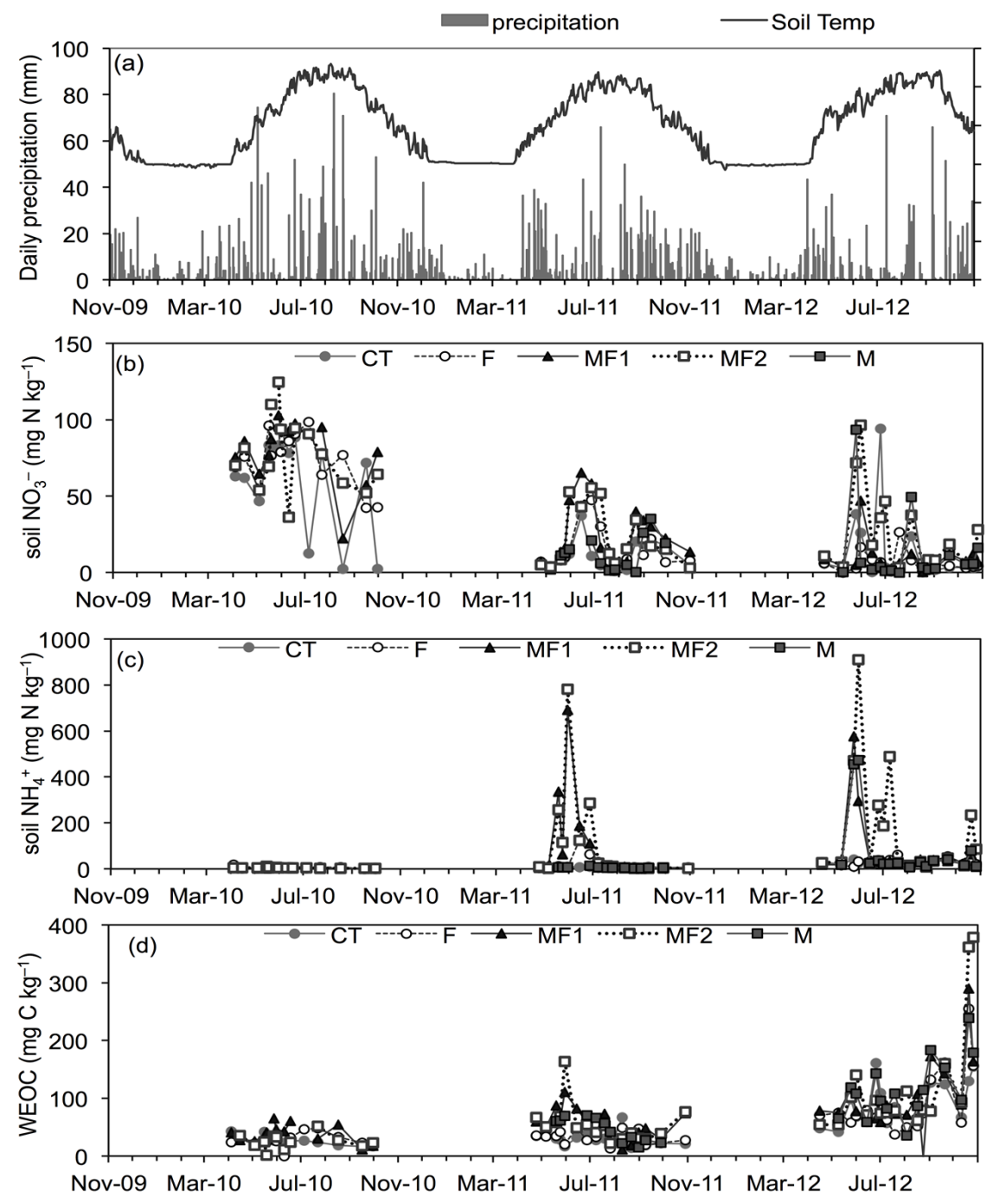

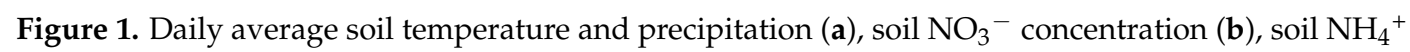
concentration (c) and water extractable soil organic carbon (WEOC) (d) from 2010 to 2012 in experiment 1. CT is unfertilized control plot; F is inorganic fertilizer-only plot; MF1 is inorganic fertilizer plus composted cattle manure applied since 2005 plot; MF2 is inorganic fertilizer plus composted cattle manure applied since 2010 plot; $\mathrm{M}$ is composted cattle manure-only plot.

Table S3 shows the total $C$ and $N$ contents measured at $0-5,5-15$ and $15-30 \mathrm{~cm}$ soil depth in the F, MF1 and MF2 plots. In all the plots, $C$ and $N$ contents were highest in the $0-5 \mathrm{~cm}$ soil depth and lowest in the 15-30 cm soil depth except in 2012 in F plot when the topsoil ( $0-5 \mathrm{~cm}$ depth) showed lower C content than the sub soil (15-30 cm depth). Soil $C$ and $N$ contents were higher in the manure-amended plots. MF1 plot which had been receiving manure for a longer period (since 2005) showed higher $C$ and N contents than MF2 which only started receiving manure in 2009/2010 season. From the soil C content, we calculated the total $C$ stock in the top $15 \mathrm{~cm}$ depth and the result clearly shows higher $C$ stock in manure-amended plots, although the differences were statistically significant only in 2012 (Table 1). 
Table 1. Total soil carbon stock (Mg C ha ${ }^{-1}$ ) in the F, MF1 and MF2 plots in 2010 and 2012 (experiment 1).

\begin{tabular}{cccc}
\hline Year & F & MF1 & MF2 \\
\hline 2010 & $84.3 \pm 10.3^{\mathrm{a}}$ & $110.9 \pm 15.9^{\mathrm{a}, \mathrm{b}}$ & $96.6 \pm 15.9^{\mathrm{a}}$ \\
2012 & $107.3 \pm 16.6^{\mathrm{a}}$ & $127.6 \pm 16.7^{\mathrm{c}}$ & $119.8 \pm 15.7^{\mathrm{b}, \mathrm{c}}$ \\
\hline
\end{tabular}

F is inorganic fertilizer-only plot; MF1 is inorganic fertilizer plus composted cattle manure applied since 2005 plot; MF2 is inorganic fertilizer plus composted cattle manure applied since 2010 plot. Different letters indicate significant differences at $p<0.05$.

\subsection{Greenhouse Gas Emissions-Experiment 1}

\subsubsection{Nitrous Oxide Emissions}

Nitrous oxide fluxes were very episodic and highly varied within and across years (Figure 2a). Intra-annual variations were highly influenced by mean daily temperature and rainfall.
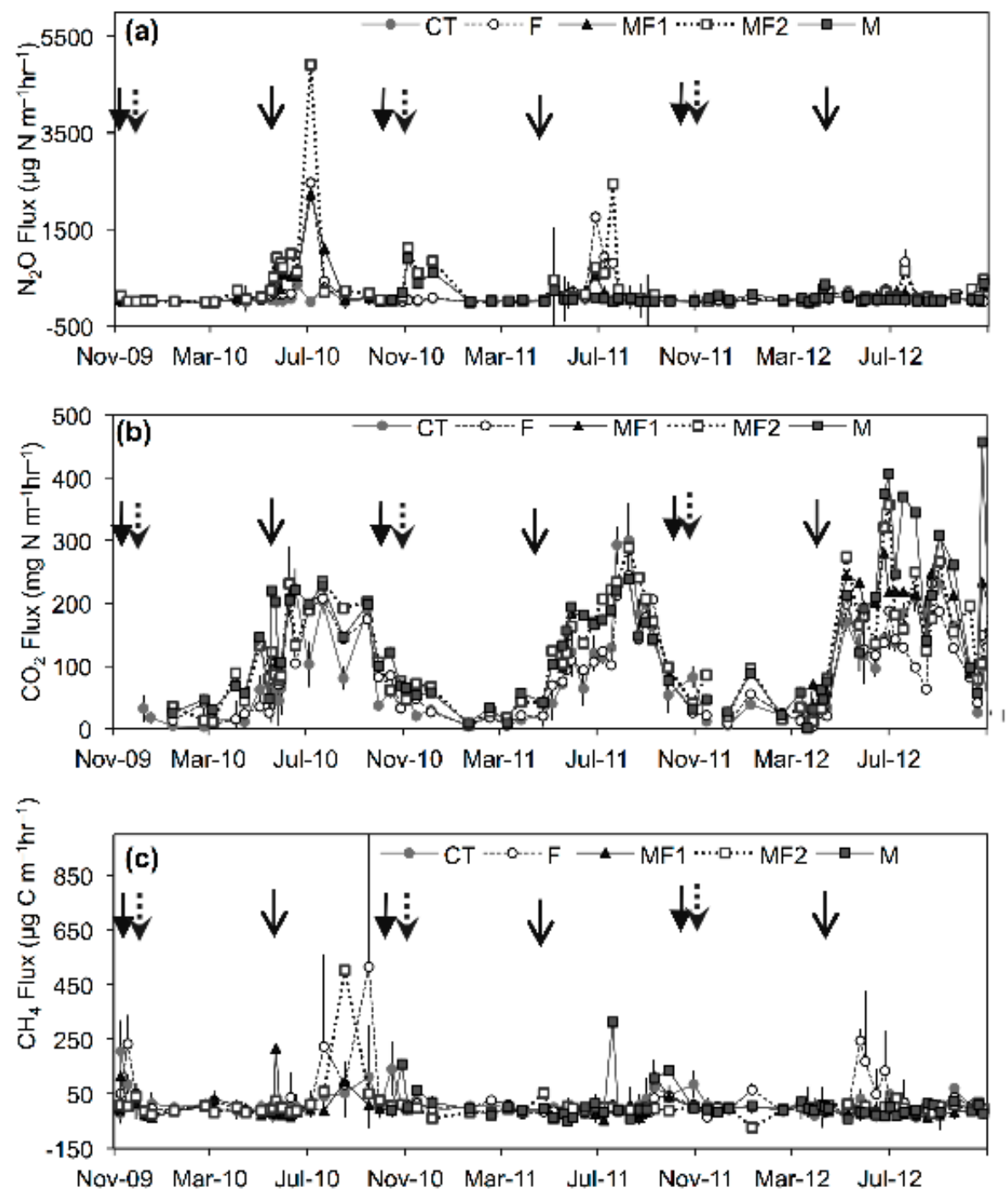

Figure 2. Seasonal variation in $\mathrm{N}_{2} \mathrm{O}$ flux (a), $\mathrm{CO}_{2}$ flux (b) and $\mathrm{CH}_{4}$ flux (c) from 2010 to 2012 in experiment 1. CT is unfertilized control plot; $\mathrm{F}$ is inorganic fertilizer-only plot; MF1 is inorganic fertilizer plus composted cattle manure applied since 2005 plot; MF2 is inorganic fertilizer plus composted cattle manure applied since 2010 plot; $\mathrm{M}$ is composted cattle manure-only plot. Full arrows with closed head indicate dates of manure application, dashed arrows indicate dates of ploughing; full arrows with open $\mathrm{V}$ shaped tip indicate dates of inorganic fertilizer application. 
As expected, $\mathrm{N}_{2} \mathrm{O}$ emissions were stimulated by fertilization and fluxes were higher in the growing season compared to the non-growing season. However, the highest $\mathrm{N}_{2} \mathrm{O}$ fluxes were observed several weeks after fertilization and occurred following rainfall events. The highest fluxes in 2010 were found on June 18 in CT plot $\left(352 \mu \mathrm{g} \mathrm{N} \mathrm{m}^{-2} \cdot \mathrm{h}^{-1}\right)$ and on July 5 in F $\left(2461 \mu \mathrm{g} \mathrm{N} \mathrm{m}{ }^{-2} \cdot \mathrm{h}^{-1}\right)$, MF1 $\left(2223 \mu \mathrm{g} \mathrm{N} \mathrm{m}^{-2} \cdot \mathrm{h}^{-1}\right)$ and MF2 $\left(4913 \mu \mathrm{g} \mathrm{N} \mathrm{m}{ }^{-2} \cdot \mathrm{h}^{-1}\right)$. High rainfall was recorded on June $16(>30 \mathrm{~mm})$ and more than $60 \mathrm{~mm}$ from 1 to 4 July. In 2011, rainfall of more than $50 \mathrm{~mm}$ was recorded between 23 and 24 June, and rainfall more than $100 \mathrm{~mm}$ was recorded between 14 and 16 July. The highest $\mathrm{N}_{2} \mathrm{O}$ fluxes in 2011 were found on 27 June in $\mathrm{F}\left(1757 \mu \mathrm{g} \mathrm{N} \mathrm{m}{ }^{-2} \cdot \mathrm{h}^{-1}\right), \mathrm{CT}\left(638 \mu \mathrm{g} \mathrm{N} \mathrm{m}{ }^{-2} \cdot \mathrm{h}^{-1}\right)$ and MF1 $\left(553 \mu \mathrm{g} \mathrm{N} \mathrm{m}{ }^{-2} \cdot \mathrm{h}^{-1}\right)$ plots, and on 19 July in MF2 plot $\left(2450 \mu \mathrm{g} \mathrm{N} \mathrm{m}{ }^{-2} \cdot \mathrm{h}^{-1}\right)$. The highest fluxes in all the five treatments in 2012 were found in either June or July and were all preceded by rainfall of more than $50 \mathrm{~mm}$.

Nitrous oxide fluxes were highest in 2010, followed by 2011 and 2012, respectively and the fluxes were higher in plots with inorganic fertilizer application (F, MF1 and MF2) compared to CT and M plots.

Total annual $\mathrm{N}_{2} \mathrm{O}$ emissions averaged $4.4 \pm 1.2,12.7 \pm 5.2,14.9 \pm 7.6,22.4 \pm 12.5$ and $8.6 \pm 4.3 \mathrm{~kg} \mathrm{~N} \mathrm{ha}^{-1} \cdot$ year $^{-1}$ for $\mathrm{CT}$ and F, MF1, MF2 and M plots, respectively (Table 2). There were significant differences in $\mathrm{N}_{2} \mathrm{O}$ emission among plots $\left(p<0.001\right.$ ) and across years (Table 2). Annual $\mathrm{N}_{2} \mathrm{O}$ emissions were highest in MF2 plot, followed by MF1 and F plots, and lowest in M and CT plots, respectively. $\mathrm{N}_{2} \mathrm{O}$ emissions in $\mathrm{M}$ and $\mathrm{CT}$ plots were not significantly different. Based on the annual emissions in Table 2, the average EFs for inorganic fertilizer were $12.9 \% \pm 15.3 \%, 7.5 \% \pm 6.8 \%$ and $3.5 \% \pm 2.9 \%$ in 2010,2011 and 2012 respectively.

Table 2. Annual manure $\mathrm{C}$ input, net primary production (NPP), $\mathrm{CO}_{2}$ emission, net ecosystem carbon balance (NECB) in $\mathrm{Mg} \mathrm{C}$ ha ${ }^{-1}$.year ${ }^{-1}, \mathrm{CH}_{4}$ emission $\left(\mathrm{kg} \mathrm{C} \mathrm{ha}^{-1}\right.$.year $\left.{ }^{-1}\right), \mathrm{N}_{2} \mathrm{O}$ emission $\left(\mathrm{kg} \mathrm{N} \mathrm{ha}^{-1} \cdot\right.$ year $\left.^{-1}\right)$ and net global warming potential (GWP) $\left(\mathrm{Mg} \mathrm{CO}_{2}-\mathrm{C}\right.$ equivalents $\mathrm{ha}^{-1} \cdot$ year $\left.^{-1}\right)$ in experiment 1 .

\begin{tabular}{|c|c|c|c|c|c|c|c|c|}
\hline \multirow{2}{*}{ Year } & \multirow{2}{*}{ Plot } & Manure & NPP & $\mathrm{CO}_{2}$ & NECB & \multirow{2}{*}{$\mathrm{CH}_{4} \mathrm{~kg} \mathrm{C}$} & \multirow{2}{*}{$\mathrm{N}_{2} \mathrm{O} \mathrm{kg} \mathrm{N}$} & \multirow{2}{*}{$\begin{array}{l}\text { GWP Mg } \\
\mathrm{CO}_{2}-\mathrm{C} \text { eq }\end{array}$} \\
\hline & & \multicolumn{4}{|c|}{$\mathrm{MgC}$} & & & \\
\hline \multirow{4}{*}{2010} & CT & 0 & $2.9 \pm 1.1^{\mathrm{c}}$ & $6.8 \pm 0.8^{\mathrm{a}, \mathrm{b}, \mathrm{c}}$ & $-6.5 \pm 0.8^{c}$ & $1.5 \pm 1.7^{\mathrm{a}, \mathrm{b}}$ & $3.9 \pm 1.2^{\mathrm{a}}$ & $7.1 \pm 1.0^{\mathrm{c}, \mathrm{d}}$ \\
\hline & $\mathrm{F}$ & 0 & $6.5 \pm 2.2^{\mathrm{a}, \mathrm{d}}$ & $6.9 \pm 1.1^{\mathrm{a}, \mathrm{b}, \mathrm{c}}$ & $-6.2 \pm 1.1^{b, c}$ & $5.1 \pm 4.6^{\mathrm{b}}$ & $17.4 \pm 16.1^{\mathrm{a}, \mathrm{b}, \mathrm{c}, \mathrm{d}}$ & $8.5 \pm 2.2^{d}$ \\
\hline & MF1 & $8.9 \pm 0.4$ & $7.0 \pm 3.7^{\mathrm{a}, \mathrm{b}, \mathrm{d}}$ & $10.2 \pm 0.7^{c}$ & $-1.7 \pm 0.7^{\mathrm{a}, \mathrm{d}}$ & $0.5 \pm 1.4^{\mathrm{a}, \mathrm{b}}$ & $22.9 \pm 11.3^{b, c, d}$ & $4.7 \pm 1.7^{\mathrm{a}, \mathrm{b}, \mathrm{c}, \mathrm{d}}$ \\
\hline & MF2 & $8.9 \pm 0.4$ & $6.1 \pm 2.3^{\mathrm{a}, \mathrm{d}, \mathrm{e}}$ & $8.9 \pm 0.5^{b, c}$ & $-0.5 \pm 0.5^{\mathrm{a}}$ & $3.7 \pm 3.9^{a, b}$ & $33.5 \pm 2.3^{d}$ & $4.9 \pm 0.4^{\mathrm{a}, \mathrm{b}, \mathrm{c}, \mathrm{d}}$ \\
\hline \multirow{5}{*}{2011} & CT & 0 & $3.5 \pm 1.3^{\mathrm{c}, \mathrm{e}}$ & $6.5 \pm 0.9^{\mathrm{a}, \mathrm{b}, \mathrm{c}}$ & $-5.7 \pm 0.9^{b, c}$ & $0.3 \pm 1.0^{\mathrm{a}, \mathrm{b}}$ & $5.8 \pm 2.3^{\mathrm{a}, \mathrm{b}}$ & $6.4 \pm 0.9^{b, c, d}$ \\
\hline & $\mathrm{F}$ & 0 & $7.6 \pm 1.3^{a, b}$ & $6.1 \pm 1.1^{\mathrm{a}, \mathrm{d}}$ & $-5.1 \pm 1.1^{b, c, e}$ & $-0.2 \pm 0.6^{\mathrm{a}}$ & $13.6 \pm 8.7^{\mathrm{a}, \mathrm{b}, \mathrm{c}}$ & $6.8 \pm 1.1^{b, c, d}$ \\
\hline & MF1 & $6.7 \pm 0.5$ & $9.9 \pm 1.2^{b}$ & $7.8 \pm 1.1^{\mathrm{a}, \mathrm{b}, \mathrm{c}}$ & $0.3 \pm 1.1^{\mathrm{a}}$ & $0.4 \pm 0.2^{\mathrm{a}, \mathrm{b}}$ & $14.3 \pm 2.2^{a, b, c}$ & $1.5 \pm 1.3^{\mathrm{a}}$ \\
\hline & MF2 & $6.7 \pm 0.5$ & $9.9 \pm 1.4^{b}$ & $8.3 \pm 1.6^{\mathrm{a}, \mathrm{b}, \mathrm{c}}$ & $0.2 \pm 1.6^{\mathrm{a}}$ & $-0.6 \pm 0.7^{\mathrm{a}}$ & $25.2 \pm 11.9^{\mathrm{c}, \mathrm{d}}$ & $3.0 \pm 2.8^{\mathrm{a}, \mathrm{b}}$ \\
\hline & M & $6.7 \pm 0.5$ & $4.3 \pm 1.6^{\mathrm{c}, \mathrm{d}, \mathrm{e}}$ & $7.8 \pm 1.1^{\mathrm{a}, \mathrm{b}, \mathrm{c}}$ & $-0.5 \pm 1.1^{\mathrm{a}}$ & $1.3 \pm 2.1^{\mathrm{a}, \mathrm{b}}$ & $11.7 \pm 2.3^{\mathrm{a}, \mathrm{b}, \mathrm{c}}$ & $2.0 \pm 1.4^{\mathrm{a}}$ \\
\hline \multirow{5}{*}{2012} & $\mathrm{CT}$ & 0 & $2.7 \pm 0.4^{\mathrm{c}}$ & $6.8 \pm 1.2^{\mathrm{a}, \mathrm{b}, \mathrm{d}}$ & $-6.2 \pm 1.2^{b, c}$ & $-0.2 \pm 0.1^{\mathrm{a}}$ & $3.6 \pm 0.7^{a}$ & $6.6 \pm 1.2^{b, c, d}$ \\
\hline & $\mathrm{F}$ & 0 & $6.3 \pm 0.8^{\mathrm{a}, \mathrm{d}, \mathrm{e}}$ & $4.9 \pm 0.3^{\mathrm{d}}$ & $-3.7 \pm 0.3^{\mathrm{b}, \mathrm{d}, \mathrm{e}}$ & $1.9 \pm 2.8^{\mathrm{a}, \mathrm{b}}$ & $7.1 \pm 3.3^{a, b}$ & $4.6 \pm 0.5^{\mathrm{a}, \mathrm{b}, \mathrm{c}, \mathrm{d}}$ \\
\hline & MF1 & $6.7 \pm 0.4$ & $8.4 \pm 1.3^{\mathrm{a}, \mathrm{b}}$ & $8.8 \pm 0.6^{\mathrm{a}, \mathrm{b}, \mathrm{c}}$ & $-1.3 \pm 0.6^{\mathrm{a}, \mathrm{d}}$ & $-0.7 \pm 0.2^{\mathrm{a}}$ & $7.7 \pm 1.2^{\mathrm{a}, \mathrm{b}}$ & $2.2 \pm 0.7^{\mathrm{a}}$ \\
\hline & MF2 & $6.7 \pm 0.4$ & $8.7 \pm 1.1^{\mathrm{a}, \mathrm{b}}$ & $9.8 \pm 2.2^{c}$ & $-2.4 \pm 2.1^{\mathrm{a}, \mathrm{d}, \mathrm{e}}$ & $0.0 \pm 0.6^{\mathrm{a}, \mathrm{b}}$ & $8.8 \pm 4.0^{\mathrm{a}, \mathrm{b}, \mathrm{c}}$ & $3.5 \pm 2.5^{\mathrm{a}, \mathrm{b}, \mathrm{c}}$ \\
\hline & M & $6.7 \pm 0.4$ & $2.9 \pm 0.9^{c}$ & $10.3 \pm 0.5^{c}$ & $-3.7 \pm 0.5^{b, d, e}$ & $-0.6 \pm 0.3^{\mathrm{a}}$ & $5.6 \pm 1.7^{\mathrm{a}, \mathrm{b}}$ & $4.4 \pm 0.8^{\mathrm{a}, \mathrm{b}, \mathrm{c}}$ \\
\hline
\end{tabular}

Different letters within the same column indicate significant differences among the treatments at $p<0.05$. CT is unfertilized control plot; F is inorganic fertilizer-only plot; MF1 is inorganic fertilizer plus composted cattle manure applied since 2005 plot; MF2 is inorganic fertilizer plus composted cattle manure applied since 2010 plot; M is composted cattle manure-only plot.

\subsubsection{Carbon Dioxide Emissions}

The pattern of $\mathrm{CO}_{2}$ fluxes was similar to those of soil temperature with the highest fluxes found in summer and lowest fluxes in winter during soil freezing period (Figure 2b). The fluxes had a significant positive exponential relationship with soil temperature measured at $5 \mathrm{~cm}$ (Figure S1). The highest recorded $\mathrm{CO}_{2}$ fluxes in each plot occurred when soil moisture content (WFPS) was lower than $65 \%$.

$\mathrm{CO}_{2}$ fluxes tended to be higher in manure plots (MF1, MF2 and M) ranging from 1.2 to $458 \mathrm{mg} \mathrm{C} \mathrm{m}{ }^{-2} \cdot \mathrm{h}^{-1}$ compare to non-manure plots ( $\mathrm{F}$ and $\mathrm{CT}$ ) which ranged from 3.1 to $299 \mathrm{mg} \mathrm{C} \mathrm{m}{ }^{-2} \cdot \mathrm{h}^{-1}$. The average cumulative annual $\mathrm{CO}_{2}$ emissions from 2010 to 2012 were $6.7 \pm 0.2$, $5.9 \pm 1.0,8.9 \pm 1.2,9.0 \pm 0.7$ and $9.0 \pm 1.7 \mathrm{MgC} \mathrm{ha}^{-1} \cdot \mathrm{year}^{-1}$ (mean $\pm \mathrm{SD}$ ) in CT, F, MF1, MF2 and M 
plots, respectively (Table 2). The annual $\mathrm{CO}_{2}$ emissions in manure-amended plots (MF1, MF2 and M) were significantly higher than in $\mathrm{F}$ and CT plots $(p<0.001)$. There was no significant difference among MF1, MF2 and M plots in annual $\mathrm{CO}_{2}$ emission. Significant differences in annual $\mathrm{CO}_{2}$ emission among plots $(p<0.001)$ and across years $(p<0.01)$ were observed and the interaction between plots and years was significant $(p<0.05)$.

\subsubsection{Methane Emissions}

Methane fluxes were mostly negative indicating $\mathrm{CH}_{4}$ consumption in all plots in this study (Figure 2c). However, there was a very wide range of fluxes ranging from $-53.6 \pm 140.7,-36.2$ to $515.5,-51.8$ to $313.1,-74.0$ to 503.0 and $-50.2 \pm 50.3 \mu \mathrm{g} \mathrm{C} \mathrm{m}{ }^{-2} \cdot \mathrm{h}^{-1}$ in CT, F, MF1, MF2 and M plots, respectively. This very wide range was due to very high fluxes $\left(>50 \mu \mathrm{g} \mathrm{C} \mathrm{m}^{-2} \cdot \mathrm{h}^{-1}\right)$ observed following rainfall of more than $40 \mathrm{~mm}$ within 4 days preceding the gas sampling or when WFPS was more than $75 \%$ in all the plots. These high $\mathrm{CH}_{4}$ fluxes accounted for less $10 \%$ of the observed data, but significantly raised the average annual fluxes. The extremely high $\mathrm{CH}_{4}$ fluxes $\left(>50 \mu \mathrm{g} \mathrm{C} \mathrm{m}{ }^{-2} \cdot \mathrm{h}^{-1}\right)$ increased the average annual flux $\left(\mu \mathrm{g} \mathrm{C} \mathrm{m}{ }^{-2} \cdot \mathrm{h}^{-1}\right.$ ) from -1.8 to 7.4 in CT plot, -2.8 to 20.8 in $\mathrm{F}$ plot, -7.5 to 1.0 in MF1, -3.2 to 5.1 in MF2 and -6.4 to 6.2 in M plot. Methane fluxes were not significantly different among the plots, but tended to be higher in CT and F plots compared to the manure-amended plots.

Annual $\mathrm{CH}_{4}$ emissions were not different among all plots but there was a significant difference across the years, and ranged from -0.7 to $5.1 \mathrm{~kg} \mathrm{C} \mathrm{ha}^{-1} \cdot$ year $^{-1}$ (Table 2). Methane emissions were significantly higher in 2010 than in 2011 and $2012(p<0.01)$. The average total annual $\mathrm{CH}_{4}$ emissions were $0.5 \pm 0.8,2.2 \pm 2.6,0.0 \pm 0.6,1.0 \pm 0.8$ and $0.3 \pm 1.3 \mathrm{~kg} \mathrm{C}^{-1} \cdot$ year $^{-1}$ in CT, F, MF1, MF2 and $\mathrm{M}$ plots, respectively, over the three-year period from 2010 to 2012. Without the extreme $\mathrm{CH}_{4}$ fluxes ( $>50 \mu \mathrm{g} \mathrm{C} \mathrm{m}{ }^{-2} \cdot \mathrm{h}^{-1}$ observed after high rainfall) all plots were net $\mathrm{CH}_{4}$ sinks.

\subsection{Effect of Additional Spring Manure Application on Greenhouse Gas Emissions-Experiment 2}

The second experiment aimed at comparing the effect of additional manure and inorganic fertilizer application in spring on GHG emissions and crop growth. From Table 3, it was clear that applying manure twice, in autumn and spring, increased the plant productivity (NPP) to the same level as the plot that received inorganic fertilizer, without a net increase in $\mathrm{CO}_{2}, \mathrm{CH}_{4}$ or $\mathrm{N}_{2} \mathrm{O}$ fluxes. This result means farmers in this region could potentially increase productivity by applying manure twice in autumn and spring even without using inorganic fertilizer. Most importantly, the second application of manure in spring led to significant increase in NECB and significant reduction in GWP compared to additional inorganic manure application (Table 3).

Table 3. Average annual manure $\mathrm{C}$ input, net primary production (NPP), $\mathrm{CO}_{2}$ emission, net ecosystem carbon balance (NECB) in $\mathrm{Mg} \mathrm{C} \mathrm{ha-1} \cdot$ year $^{-1}, \mathrm{CH}_{4}$ emission $\left(\mathrm{kg} \mathrm{C} \mathrm{ha}^{-1}\right.$.year $\left.{ }^{-1}\right), \mathrm{N}_{2} \mathrm{O}$ emission $\left(\mathrm{kg} \mathrm{N} \mathrm{ha}^{-1}\right.$.year $\left.{ }^{-1}\right)$ and global warming potential (GWP) $\left(\mathrm{Mg} \mathrm{CO}_{2}-\mathrm{C}\right.$ equivalents $\mathrm{ha}^{-1}$. year $\left.^{-1}\right)$ in experiment 2 .

\begin{tabular}{|c|c|c|c|c|c|c|c|}
\hline \multirow{2}{*}{ Plot } & Manure & NPP & $\mathrm{CO}_{2}$ & NECB & \multirow{2}{*}{$\mathrm{N}_{2} \mathrm{O}$ kg N } & \multirow{2}{*}{$\mathrm{CH}_{4} \mathrm{~kg} \mathrm{C}$} & \multirow{2}{*}{$\begin{array}{l}\text { GWP Mg } \\
\mathrm{CO}_{2} \text {-C eq }\end{array}$} \\
\hline & \multicolumn{4}{|c|}{$\operatorname{MgC}$} & & & \\
\hline M1 & $7.3 \pm 0.3^{a}$ & $3.94 \pm 0.46^{b}$ & $8.28 \pm 1.70$ & $0.59 \pm 1.7^{b}$ & $7.19 \pm 1.77$ & $-0.04 \pm 0.37$ & $0.33 \pm 1.75^{\mathrm{a}}$ \\
\hline MF & $7.3 \pm 0.3^{a}$ & $6.99 \pm 2.52^{\mathrm{a}}$ & $8.71 \pm 1.64$ & $0.20 \pm 1.6^{b}$ & $10.00 \pm 1.83$ & $-0.29 \pm 0.24$ & $1.08 \pm 1.74^{\mathrm{a}}$ \\
\hline MM & $12.3 \pm 0.4^{b}$ & $7.12 \pm 1.00^{\mathrm{a}}$ & $8.30 \pm 1.72$ & $5.22 \pm 1.7^{\mathrm{a}}$ & $7.41 \pm 1.39$ & $0.18 \pm 0.23$ & $-4.27 \pm 1.81^{b}$ \\
\hline
\end{tabular}

Different letters within the same column indicate significant differences among the treatments at $p<0.05$. M1 is autumn composted cattle manure application only plot; MF is autumn composted cattle manure plus spring inorganic fertilizer plot; $\mathrm{MM}$ is autumn composted cattle manure plus additional spring composted cattle manure plot. 


\subsection{Factors Controlling GHG Emissions}

Nitrous oxide fluxes had statistically significant $(p<0.01)$ positive linear regression relationships with soil temperature and soil $\mathrm{NO}_{3}{ }^{-}$concentration and a significant negative relationship with soil $\mathrm{pH}$ (Table 4). Cumulative annual $\mathrm{N}_{2} \mathrm{O}$ emissions showed significant positive linear relationships with $\mathrm{N}$ input $(r=0.62, p<0.05)$ and precipitation in growing season $(r=0.56, p<0.05)$, and a negative linear relationship with soil $\mathrm{pH}(r=-0.72, p<0.01)$. Average annual $\mathrm{N}_{2} \mathrm{O}$ emission in MF1 plot was lower than in MF2 plot despite both plots receiving the same amount of manure and inorganic fertilizer possibly due to the lower $\mathrm{pH}$ in MF2. This seems to suggest that long-term manure application in MF1 buffered against lowering of $\mathrm{pH}$ by inorganic fertilizer application.

Table 4. Linear regressions (Pearson's correlation coefficients) for the relationship between greenhouse gas fluxes and environmental variables (experiments 1 and 2 combined).

\begin{tabular}{cccc}
\hline Variable & $\mathbf{N}_{\mathbf{2}} \mathbf{O}$ Flux $\left(\mu \mathrm{g} \mathrm{N} \mathrm{m}^{-\mathbf{2}} \cdot \mathbf{h}^{-\mathbf{1}}\right)$ & $\mathbf{C H}_{\mathbf{4}}$ Flux $\left(\mu \mathrm{g} \mathrm{C} \mathrm{m}^{-\mathbf{2}} \cdot \mathbf{h}^{-\mathbf{1}}\right)$ & $\mathrm{CO}_{\mathbf{2}}$ Flux $\left(\mathrm{mg} \mathrm{C} \mathrm{m}^{-\mathbf{2}} \cdot \mathbf{h}^{-\mathbf{1}}\right)$ \\
\hline Soil temperature & $0.174^{* *}$ & $0.163^{* *}$ & $0.776^{* *}$ \\
WFPS & 0.084 & $0.205^{* *}$ & $-0.341^{* *}$ \\
Soil pH & $-0.281^{* *}$ & -0.060 & $0.162^{*}$ \\
$\mathrm{NO}_{3}{ }^{-}$ & $0.242^{* *}$ & 0.031 & $-0.265^{* *}$ \\
$\mathrm{NH}_{4}{ }^{*}$ & -0.049 & -0.067 & 0.069 \\
WEOC & 0.031 & -0.113 & 0.105 \\
\hline
\end{tabular}

WFPS is water filled pore space, WEOC is water extractable organic carbon. ** Significant correlation at $p<0.01$, * significant correlation at $p<0.05$.

Methane fluxes were significantly correlated with soil temperature and moisture. Soil moisture seemed to be the most important factor driving $\mathrm{CH}_{4}$ fluxes and all the disproportionately high fluxes ( $>50 \mu \mathrm{g} \mathrm{CH} \mathrm{CH}_{4}-\mathrm{C} \mathrm{m}^{-2} \cdot \mathrm{h}^{-1}$ ) were observed when soil WFPS was more than $70 \%$. Soil chemical properties did not show any significant correlations with the instantaneous $\mathrm{CH}_{4}$ fluxes (Table 4). However, cumulative annual $\mathrm{CH}_{4}$ emissions had significant linear relationships with soil $\mathrm{NO}_{3}{ }^{-}$ $(r=0.66, p<0.01)$ and soil $\mathrm{pH}(r=-0.61, p<0.05)$.

Soil $\mathrm{CO}_{2}$ fluxes had positive and significant linear relationships with soil $\mathrm{pH}$ and soil temperature and significant negative correlation with soil $\mathrm{NO}_{3}{ }^{-}$concentration and soil WFPS (Table 4). The $\mathrm{CO}_{2}$ flux increased exponentially with increasing soil temperature (Figure S1) and the resulting Q10 values were 3.2, 2.8, 2.3, 2.5 and 2.3 in the CT, F, MF1, MF2 and M plots, respectively. The annual $\mathrm{CO}_{2}$ emissions significantly increased with manure application $(p<0.01)$ and this could be largely due to the $\mathrm{C}$ input from manure. Multivariate regression analysis showed that soil temperature, WFPS and WEOC concentration explained $55 \%$ of the seasonal variation in $\mathrm{CO}_{2}$ fluxes $\left(\mathrm{CO}_{2}\right.$ flux $\left(\mathrm{mg} \mathrm{C} \mathrm{m}^{-2} \cdot \mathrm{h}^{-1}\right)=-98.89+11.86$ soil temperature -2.57 WFPS $(\%)+0.32$ WEOC $\left.\left(\mathrm{mg} \mathrm{C} \mathrm{kg}^{-1}\right) ; R^{2}=0.55 ; p<0.001\right)$.

\subsection{Effect of Fertilizer and Manure on NPP, NECB, GWP and GHGI}

Inorganic fertilizer significantly increased the net primary production (NPP) in each of the three years in experiment one and also in 2013 in experiment two (Tables 2 and 3). However due to $C$ export from the field through the harvested material, inorganic fertilizer did not increase NECB. Manure application, on the other hand, had a positive but non-significant effect on NPP in experiment 1. However the second application of manure in spring in experiment 2 significantly increased NPP (Table 3), and there was no significant difference between MF and MM plots. Manure input in both experiments 1 and 2 significantly increased NECB.

Global warming potentials, in experiment 1, were lowest in MF1 and MF2 plots and highest in F and CT plots (Table 2). Global warming potential ranged from 6.4 to $7.1 \mathrm{Mg} \mathrm{CO}_{2}-\mathrm{C}$ eq.ha ${ }^{-1} \cdot \mathrm{year}^{-1}$ in the unfertilized control. Both inorganic and manure fertilization showed potential to reduce the GWPs mainly due to $C$ addition from the manure and also from the increased plant biomass residue 
left after harvest. In experiment 2, high manure input in MM plot significantly raised the NECB and as a result the GWP was negative. Net ecosystem $C$ balance had the largest contribution to GWP and consequently, manure application seemed to significantly reduce GWP.

Greenhouse gas intensities, presented in Figure 3, were different among the plots. The control plot always had the highest GHGI followed by F plot. Combined manure and inorganic fertilizer plots (MF1 and MF2) always had the lowest GHGIs due to high C input through manure and also high crop residue addition as both had higher NPP and yield. Greenhouse gas intensity in M plot was lower than that in F plot in 2011, but the opposite in 2012.

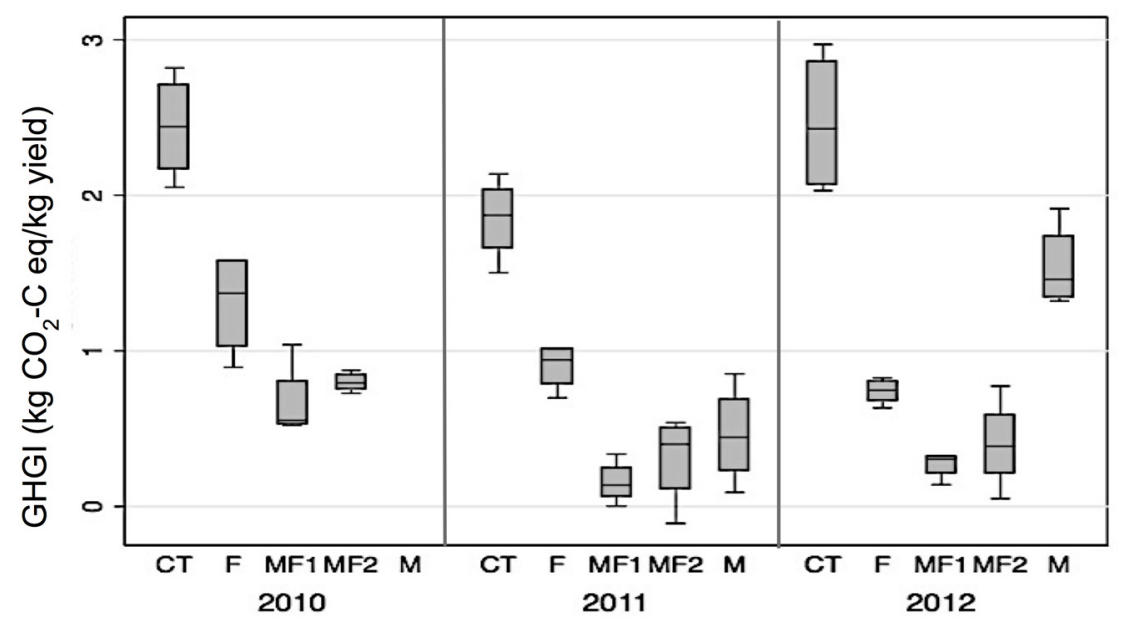

Figure 3. Greenhouse gas intensity (GHGI) in 2010-2012 (experiment 1). CT is unfertilized control plot; $\mathrm{F}$ is inorganic fertilizer-only plot; MF1 is inorganic fertilizer plus composted cattle manure applied since 2005 plot; MF2 is inorganic fertilizer plus composted cattle manure applied since 2010 plot; M is composted cattle manure-only plot.

\section{Discussion}

\subsection{Influence of Inorganic Fertilizer and Manure Application on GHG Emissions}

Application of inorganic and manure fertilizers increased $\mathrm{N}_{2} \mathrm{O}$ emissions by $2-5$ times compared to the unfertilized control treatment (Table 2). Carbon dioxide fluxes only increased following manure application but not inorganic fertilizer application. Neither inorganic nor manure fertilization seemed to significantly influence $\mathrm{CH}_{4}$ fluxes.

Increased $\mathrm{N}_{2} \mathrm{O}$ emissions with increased $\mathrm{N}$ addition was expected as it is widely reported that the two most important $\mathrm{N}_{2} \mathrm{O}$ production pathways in the soils, nitrification and denitrification, are stimulated by high $\mathrm{N}$ input $[13,41,50-53]$. In this study, the average inorganic fertilizer $\mathrm{N}_{2} \mathrm{O}$ emission factor was $7.8 \%$ (ranging from $3.5 \%$ to $12.9 \%$ ), which was significantly higher than the default IPCC value of $1 \%$ and also higher than several published values of between $0.1 \%$ to $3 \%$ [54-57]. However, our emission factors were similar to those reported by Flessa and Dorsh [58] in Germany of $5.1 \%-8.8 \%$ in a wheat field and by Mackenzie et al. [59] of $0 \%-8 \%$ in corn field. High emission factors in this study could be due to the relatively high soil $\mathrm{NO}_{3}{ }^{-}$concentrations especially in 2010 . The reason for the high $\mathrm{NO}_{3}{ }^{-}$content could have been due to the stimulation of litter and organic matter decomposition and mineralization after the conversion from grassland to cornfield in November 2009. The manure $\mathrm{N}_{2} \mathrm{O}$ emission factors ranged from $0.2 \%$ to $0.9 \%$ and are similar to those reported by Collins et al. [60] (0.05\%-0.1\%) and Akiyama et al. [61] (0.01\%-1.6\%).

Despite both manure and inorganic fertilizers increasing $\mathrm{N}_{2} \mathrm{O}$ emissions, the manure-only treatments had significantly lower emissions than the inorganic fertilizer plot. In experiment 2 , manure application in MM plot was done twice and at almost twice the amount of that applied in M1 plot but did not lead to increased $\mathrm{N}_{2} \mathrm{O}$ emissions (Table 3), and almost doubled the net primary production. 
Nitrous oxide emissions and plant productivity in MM and MF plots were similar which suggests that application of manure twice instead of once can enable organic farmers achieve similar productivity levels with conventional farmers using inorganic fertilizers.

More than 5 years of manure application (MF1 and M plots in experiment 1) had an added positive influence of maintaining higher $\mathrm{pH}$ values than the inorganic fertilized plot and this could have further benefits in reducing the $\mathrm{N}_{2} \mathrm{O}$ emissions given the strong negative relationship between soil $\mathrm{pH}$ and $\mathrm{N}_{2} \mathrm{O}$ emissions (Figure $\mathrm{S} 2$ ). Manure application increased and maintained soil $\mathrm{pH}$ by increasing the buffering capacity of soils due to the presence of carboxyl and phenolic hydroxyl groups in the manure [62] or due the high $\mathrm{pH}$ of the manure itself (manure $\mathrm{pH}$ was around 7). Presence of cations (like calcium, magnesium, etc.) and organic $\mathrm{N}$ forms in manure could have also increased the soil $\mathrm{pH}$ in manure-amended treatments [62].

High $\mathrm{CH}_{4}$ emission in inorganic fertilizer amended soils due to fertilizer $\mathrm{N}$ inhibition of $\mathrm{CH}_{4}$ oxidation has been reported in many studies [51,63]. We did not find the evidence of higher $\mathrm{CH}_{4}$ emissions in plots amended with inorganic fertilizer in this study and there was no significant difference in annual $\mathrm{CH}_{4}$ emissions among the plots. However, the highest $\mathrm{CH}_{4}$ fluxes were always found in the fertilized plots (Figure 2c) and there was a significant positive correlation between average annual $\mathrm{CH}_{4}$ flux and average annual soil mineral $\mathrm{N}$ concentration $\left(R^{2}=0.65, p<0.05\right)$. This might suggest inhibition of $\mathrm{CH}_{4}$ oxidation when soil mineral $\mathrm{N}$ is high $[5,7,64]$.

Carbon dioxide fluxes and cumulative annual emissions significantly increased due to manure application but not due to inorganic fertilization. Increased availability of $C$ substrates from the manure was likely the major reason for the observed result [4,29,65-67].

\subsection{Soil and Environmental Factors Controlling GHG Emissions}

Key soil and climatic variables controlling all the three GHG emissions in this study were soil temperature, soil moisture and rainfall. Soil $\mathrm{NO}_{3}{ }^{-}$concentrations and soil $\mathrm{pH}$ were important factors for $\mathrm{N}_{2} \mathrm{O}$ and $\mathrm{CO}_{2}$ (Table 4).

While soil $\mathrm{N}_{2} \mathrm{O}$ fluxes were heavily influenced by $\mathrm{N}$ fertilization (both inorganic and manure), the highest fluxes were all found just after rainfall of more than $30 \mathrm{~mm}$ within the week preceding the flux measurement date. Ryals and Silver [68] also reported elevated $\mathrm{N}_{2} \mathrm{O}$ up to four days from the wetting of soils. Annual $\mathrm{N}_{2} \mathrm{O}$ emissions were also very high in 2010, which was the wettest year. Other studies have reported high $\mathrm{N}_{2} \mathrm{O}$ emission when rainfall and moisture are high [4,69-71]. The high $\mathrm{N}_{2} \mathrm{O}$ fluxes observed after high rainfall were likely due to denitrification $[4,34,71]$ as a result of increased soil moisture.

Soil $\mathrm{pH}$ was a major factor controlling annual $\mathrm{N}_{2} \mathrm{O}$ emissions and this agrees with previous reports [72,73]. The $\mathrm{N}_{2} \mathrm{O}$ reductase enzyme is reported to be more active at low soil $\mathrm{pH}$ relative to activities of $\mathrm{NO}_{3}{ }^{-}$and $\mathrm{NO}_{2}{ }^{-}$reductase enzymes [73], which could have resulted in the reduced $\mathrm{N}_{2} \mathrm{O}$ reduction to $\mathrm{N}_{2}$ during denitrification and consequently higher fluxes at low soil $\mathrm{pH}$.

The most important factors controlling $\mathrm{CH}_{4}$ emission in this study were soil moisture and temperature. Very high $\mathrm{CH}_{4}$ fluxes were observed when WFPS was $75 \%$ or higher. Less than $10 \%$ of the total $\mathrm{CH}_{4}$ flux measurements (all recorded when WFPS > 75\%) accounted for $50 \%-150 \%$ of the cumulative average annual $\mathrm{CH}_{4}$ emissions. These high $\mathrm{CH}_{4}$ fluxes significantly reduced $\mathrm{CH}_{4}$ sink in soil and were solely responsible for the observed positive cumulative annual $\mathrm{CH}_{4}$ emissions. This indicates that while this upland cornfield was generally a sink for $\mathrm{CH}_{4}$ under usual moisture levels, increased occurrence of high rainfall and soil moisture above 75\% WFPS could lead to significant $\mathrm{CH}_{4}$ emissions. Several studies have reported WFPS value of $70 \%-75 \%$ as the optimum for high $\mathrm{CH}_{4}$ production [10,74-76] and this could be due to both low production of $\mathrm{CH}_{4}$ and low air permeability at high WFPS levels [5].

Carbon dioxide flux is influenced by soil temperature, moisture content and availability of $\mathrm{C}$ substrates [74-80]. The relationship between soil temperature and $\mathrm{CO}_{2}$ flux (Figure S1) in this study was best described by an exponential curve and this agrees with several published studies [81-84]. 
From the exponential curves, we estimated average Q10 values and these were 3.2, 2.8, 2.3, 2.5 and 2.3 in the CT, F, MF1, MF2 and M plots, respectively. These Q10 values are in agreement with reported values from other studies $[74,78,80,85]$. From these values, it seems manure application led to slightly lower Q10 values despite the manure plots having higher WEOC, although we can not make definite conclusions from this study. If this was true, it would be contrary to Liu et al. [85] who reported higher $\mathrm{Q} 10$ values when WEOC was high. The seemingly lower $\mathrm{Q} 10$ values in manure-amended plots might be due to the larger influence of manure $\mathrm{C}$ on $\mathrm{CO}_{2}$ emissions.

Soil $\mathrm{CO}_{2}$ flux negatively correlated to soil WFPS (Table 4) with highest fluxes found when WFPS was between $40 \%$ and $60 \%$. This WFPS range also showed the lowest $\mathrm{CH}_{4}$ fluxes. A conclusion can therefore be made that there was high $C$ oxidation when WFPS was low and the opposite was true when WFPS was above $70 \%[54,86]$.

\subsection{Effect of Fertilizer and Manure on NECB and GWP}

Carbon sequestration calculations should include all $C$ inputs and losses in an agro-ecosystem $[17,38,87,88]$. The calculated NECB values in this study show that manure application is important for increased $C$ sequestration as a direct $C$ input and it significantly mitigates the $\mathrm{C}$ losses from harvested $\mathrm{C}$ and $\mathrm{CO}_{2}$ emission (Table 2). While all plots showed negative NECB values in 2010 and 2012, the NECB in manure plots was significantly higher. Results from experiment 2 show that applying manure twice in autumn and spring significantly increased NECB through direct $C$ input but also by increasing the net primary production and hence the $C$ input through residue left in the field. The effect of fertilization on soil $C$ pools is related to the amount of $C$ applied and $C$ produced/retained to the soil [89]. High NECB in MM plot in experiment 2 was achieved without increased emissions of $\mathrm{CO}_{2}, \mathrm{CH}_{4}$ or $\mathrm{N}_{2} \mathrm{O}$ compared to the plot with combined manure and fertilizer application (Table 3). Higher NECB values, indicating increased C sequestration [17], in manure amended plots have been reported previously [32,87]. Total soil $\mathrm{C}$ content and total $\mathrm{C}$ stock, measured in 2010 and 2012, were higher in manure-amended plots (Table 1 and S3) indicating higher $\mathrm{C}$ sequestration due to manure application. Compared to the non-manure plot, manure application increased soil $C$ stock in the top $15 \mathrm{~cm}$ by $20.7 \pm 11.7 \mathrm{Mg} \mathrm{C} \mathrm{ha}^{-1}$ which is similar to $19 \mathrm{Mg} \mathrm{C} \mathrm{ha}^{-1}$ reported by Owen et al. [64]. Pathak et al. [19] also reported higher $C$ accumulation when farmyard manure was applied along with inorganic fertilizer.

Adequate manure application done twice in spring and autumn show a potential to increase not only the plant productivity to the same level of inorganic fertilized plot but also with the added benefit of storing more $C$ in the soil as evidenced from results of experiment 2. Net GWP values (Table 2) and GHGIs (Figure 3) show that combined manure and inorganic fertilization had the highest potential for mitigating net GHG emissions, which we attribute to both increased NPP and also to increased direct $C$ input into the soil. Composted manure application has been shown in other studies to reduce net GHG emissions $[17,64]$. Without consideration of the $\mathrm{C}$ input from manure, GWP values (from $\mathrm{N}_{2} \mathrm{O}$ and $\mathrm{CH}_{4}$ ) were significantly lower in the unfertilized control plot and highest in the inorganic fertilized treatments but there were no significant differences in the net GWPs of the manure plus inorganic fertilizer (MF) and inorganic fertilizer-only (F) plots (Table S4). However, when these GWP values were yield-scaled (GHGI) no significant differences were observed among the plots (Table S4). This clearly shows that when evaluating effects of manure and fertilizer management on net GHG emissions, the benefits obtained from increased productivity should be considered. Further research to determine the optimum application rates and ratios of the inorganic fertilizer and composted manure is recommended. $\mathrm{N}_{2} \mathrm{O}$ emissions were more stimulated by inorganic fertilizer than by composted manure and therefore reduced application of inorganic fertilizer and partial substitution with composted manure could help reduce net GHG emissions, a result which has been found in other studies $[56,75,90]$. 


\section{Conclusions}

In this three-year field study, we evaluated the effect of inorganic fertilizer and composted cattle manure application on GHGs, GWPs and GHGI in a cornfield. Nitrous oxide emissions increased following both inorganic and manure application although we did not find significant influence of manure and inorganic fertilizer in 2012. Methane fluxes were not influenced by the soil amendments while $\mathrm{CO}_{2}$ fluxes increased with manure application. By applying manure twice, in autumn and spring in experiment 2, high plant productivity was achieved without increased GHG emissions compared to one-time manure application. Our study found that application of manure led to significant reductions in net GWP and GHGI and this was largely due to direct C input to the soil and also through increased plant productivity.

Measured $\mathrm{N}_{2} \mathrm{O}$ fluxes were significantly elevated by rainfall of more than $30 \mathrm{~mm}$ within 7 days just before flux measurement. Cumulative $\mathrm{N}_{2} \mathrm{O}$ emissions were controlled by soil $\mathrm{pH}$, growing season rainfall and soil mineral $\mathrm{N}$ concentration. Less than $10 \%$ of $\mathrm{CH}_{4}$ measurements accounted for $50 \%-100 \%$ of the total annual emissions and these were all observed when WFPS was more than $70 \%$. Soil temperature influenced the seasonal change in $\mathrm{CO}_{2}$ emissions, and manure application seemed to reduce the $\mathrm{Q} 10$ values of heterotrophic soil respiration.

Supplementary Materials: The following are available online at www.mdpi.com/2077-0472/7/2/0013/S1 as supplementary data; Figure S1: Relationship between soil temperature $(5 \mathrm{~cm})$ and $\mathrm{CO}_{2}$ flux in experiment 1 , Figure S2: Relationship between annual $\mathrm{N}_{2} \mathrm{O}$ emission and annual average soil $\mathrm{pH}$ (data from experiment 1 ), Table S1: Rates of inorganic fertilizer nitrogen and gross manure carbon and manure nitrogen input from 2010 to 2012 (Experiment 1), Table S2: Rates of inorganic fertilizer nitrogen and gross manure carbon and manure nitrogen input in experiment 2, Table S3: Soil carbon and nitrogen content (\% per kilogram of soil) in the F, MF1 and MF2 plots (in experiment 1) in each soil depth in 2010 and 2012 and Table S4: Average annual $\mathrm{CH}_{4}$ and $\mathrm{N}_{2} \mathrm{O}$ emissions (in carbon dioxide equivalents; $\mathrm{CO}_{2}$-eq), net global warming potential (GWP) and net greenhouse gas intensity (GHGI) from $\mathrm{CH}_{4}$ and $\mathrm{N}_{2} \mathrm{O}$ in experiment 1.

Acknowledgments: This study was partly supported by a research grant provided by the Project "Development of Mitigation Technologies to Climate Change in the Agriculture Sector (FY 2010-2014)" run by Ministry of Agriculture, Forestry and Fisheries of Japan. The author thanks the staff and management of the Hokkaido University's Shizunai Livestock experimental farm for their assistance in field management activities.

Author Contributions: I.M., S.M. and R.H. conceived and designed the experiment; I.M. and S.M. performed the experiment; R.H. provided reagents/materials/analysis tools; I.M. wrote the paper.

Conflicts of Interest: The authors declare no conflict of interest.

\section{References}

1. Innternational Panel Climate Change. Climate Change 2007: The Physical Science Basis; Contribution of Working Group I to the Fourth Assessment Report of the Intergovernmental Panel on Climate Change; Solomon, S., Qin, D., Manning, M., Chen, Z., Marquis, M., Averyt, K.B., Tignor, M., Miller, H.L., Eds.; Cambridge University Press: Cambridge, UK; New York, NY, USA, 2007.

2. Smith, P.; Martino, D.; Cai, Z.; Gwary, D.; Janzen, H.; Kumar, P.; Mccarl, B.; Ogle, S.; Mara, F.O.; Rice, C.; et al. Greenhouse gas mitigation in agriculture. Philos. Trans. R. Soc. B 2008, 363, 789-813. [CrossRef] [PubMed]

3. Smith, P.; Bustamante, M.; Ahammad, H.; Clark, H.; Dong, H.; Elsiddig, E.; Haberl, H.; Harper, R.; House, J.; Jafari, M.; et al. Agriculture, Forestry and Other Land Use (AFOLU). In Climate Change 2014: Mitigation of Climate Change. Contribution of Working Group III to the Fifth Assessment Report of the Intergovernmental Panel on Climate Change; Edenhofer, O., Pichs-Madruga, R., Sokona, Y., Farahani, E., Kadner, S., Seyboth, K., Adler, A., Baum, I., Brunner, S., Eickemeier, P., et al., Eds.; Cambridge University Press: Cambridge, UK; New York, NY, USA, 2014; pp. 811-922.

4. Alluvione, F.; Bertora, C.; Zavattaro, L.; Grignani, C. Nitrous Oxide and Carbon Dioxide Emissions Following Green Manure and Compost Fertilization in Corn. Soil Sci. Soc. Am. J. 2010, 74, 384. [CrossRef]

5. Tate, K.R. Soil methane oxidation and land-use change-From process to mitigation. Soil Biol. Biochem. 2015, 80, 260-272. [CrossRef]

6. Bayer, C.; Gomes, J.; Vieira, F.C.B.; Zanatta, J.A.; De Cássia Piccolo, M.; Dieckow, J. Methane emission from soil under long-term no-till cropping systems. Soil Tillage Res. 2012, 124, 1-7. [CrossRef] 
7. MacDonald, J.A.; Skiba, U.; Sheppard, L.J.; Ball, B.; Roberts, J.D.; Smith, K.A.; Fowler, D. The effect of nitrogen deposition and seasonal variability on methane oxidation and nitrous oxide emission rates in an upland spruce plantation and moorland. Atmos. Environ. 1997, 31, 3693-3706. [CrossRef]

8. Saggar, S. Estimation of nitrous oxide emission from ecosystems and its mitigation technologies. Agric. Ecosyst. Environ. 2010, 136, 189-191. [CrossRef]

9. Dobbie, K.; Smith, K.; Management, R.; Building, D.; Road, M. Nitrous oxide emission factors for agricultural soils in Great Britain: The impact of soil water filled pore space and other controlling variables. Glob. Chang. Biol. 2003, 9, 204-218. [CrossRef]

10. Mazzetto, A.M.; Barneze, A.S.; Feigl, B.J.; van Groenigen, J.W.; Oenema, O.; Cerri, C.C. Temperature and moisture affect methane and nitrous oxide emission from bovine manure patches in tropical conditions. Soil Biol. Biochem. 2014, 76, 242-248. [CrossRef]

11. Allen, D.E.; Kingston, G.; Rennenberg, H.; Dalal, R.C.; Schmidt, S. Effect of nitrogen fertilizer management and waterlogging on nitrous oxide emission from subtropical sugarcane soils. Agric. Ecosyst. Environ. 2010, 136, 209-217. [CrossRef]

12. Li, L.; Han, X.; You, M.; Horwath, W.R. Nitrous oxide emissions from Mollisols as affected by long-term applications of organic amendments and chemical fertilizers. Sci. Total Environ. 2013, 452-453, 302-308. [CrossRef] [PubMed]

13. Shcherbak, I.; Millar, N.; Robertson, G.P. Global metaanalysis of the nonlinear response of soil nitrous oxide $\left(\mathrm{N}_{2} \mathrm{O}\right)$ emissions to fertilizer nitrogen. Proc. Natl. Acad. Sci. USA 2014, 111, 9199-9204. [CrossRef] [PubMed]

14. Davidson, E.A.; Nepstad, D.C.; Ishida, F.Y.; Brando, P.M. Effects of an experimental drought and recovery on soil emissions of carbon dioxide, methane, nitrous oxide, and nitric oxide in a moist tropical forest. Glob. Chang. Biol. 2008, 14, 2582-2590. [CrossRef]

15. Smith, P.; Martino, D.; Cai, Z.; Gwary, D.; Janzen, H.; Kumar, P.; McCarl, B.; Ogle, S.; O’Mara, F.; Rice, C.; et al. Agriculture; Metz, B., Davidson, O.R., Bosch, P.R., Dave, R., Meyer, L.A., Eds.; Cambridge University Press: Cambridge, UK; New York, NY, USA, 2007; Volume 9.

16. Food and Agriculture Organization of the United Nations (FAO); International Fertilizer Industry Association (IFA). IFA Global Estimates of Gaseous Emissions of $\mathrm{NH}_{3}, \mathrm{NO}$ and $\mathrm{N}_{2} \mathrm{O}$ from Agricultural Land; FAO: Rome, Italy, 2001.

17. Zhang, W.; Yu, Y.; Li, T.; Sun, W.; Huang, Y. Net greenhouse gas balance in China's croplands over the last three decades and its mitigation potential. Environ. Sci. Technol. 2014, 48, 2589-2597. [CrossRef] [PubMed]

18. Ali, M.A.; Kim, P.J.; Inubushi, K. Mitigating yield-scaled greenhouse gas emissions through combined application of soil amendments: A comparative study between temperate and subtropical rice paddy soils. Sci. Total Environ. 2015, 529, 140-148. [CrossRef] [PubMed]

19. Pathak, H.; Byjesh, K.; Chakrabarti, B.; Aggarwal, P.K. Potential and cost of carbon sequestration in Indian agriculture: Estimates from long-term field experiments. Filed Crops Res. 2011, 120, 102-111. [CrossRef]

20. Bayer, C.; Gomes, J.; Accordi, J.; Costa, F.; Vieira, B.; Dieckow, J. Mitigating greenhouse gas emissions from a subtropical Ultisol by using long-term no-tillage in combination with legume cover crops. Soil Tillage Res. 2016, 161, 86-94. [CrossRef]

21. Barton, L.; Hoyle, F.C.; Stefanova, K.T.; Murphy, D.V. Incorporating organic matter alters soil greenhouse gas emissions and increases grain yield in a semi-arid climate. Agric. Ecosyst. Environ. 2016, 231, 320-330. [CrossRef]

22. Sommer, R.; Mukalama, J.; Kihara, J.; Koala, S.; Winowiecki, L.; Bossio, D. Nitrogen dynamics and nitrous oxide emissions in a long-term trial on integrated soil fertility management in Western Kenya. Nutr. Cycl. Agroecosyst. 2016, 105, 229-248. [CrossRef]

23. Huth, N.I.; Thorburn, P.J.; Radford, B.J.; Thornton, C.M. Impacts of fertilisers and legumes on $\mathrm{N}_{2} \mathrm{O}$ and $\mathrm{CO}_{2}$ emissions from soils in subtropical agricultural systems: A simulation study. Agric. Ecosyst. Environ. 2010, 136, 351-357. [CrossRef]

24. Rochette, P.; Angers, D.A.; Chantigny, M.H.; Bertrand, N.; Côté, D. Carbon Dioxide and Nitrous Oxide Emissions following Fall and Spring Applications of Pig Slurry to an Agricultural Soil. Soil Sci. Soc. Am. J. 2004, 68, 1410. [CrossRef]

25. Smith, K.A.; McTaggart, I.P.; Tsuruta, H. Emissions of $\mathrm{N}_{2} \mathrm{O}$ and $\mathrm{NO}$ associated with nitrogen fertilization in intensive agriculture, and the potential for mitigation. Soil Use Manag. 1997, 13, 296-304. [CrossRef] 
26. Cui, F.; Yan, G.; Zhou, Z.; Zheng, X.; Deng, J. Annual emissions of nitrous oxide and nitric oxide from a wheat-maize cropping system on a silt loam calcareous soil in the North China Plain. Soil Biol. Biochem. 2012, 48, 10-19. [CrossRef]

27. Jarecki, M.K.; Lal, R.; James, R. Crop management effects on soil carbon sequestration on selected farmers' fields in northeastern Ohio. Soil Tillage Res. 2005, 81, 265-276. [CrossRef]

28. Ryals, R.; Kaiser, M.; Torn, M.S.; Berhe, A.A.; Silver, W.L. Impacts of organic matter amendments on carbon and nitrogen dynamics in grassland soils. Soil Biol. Biochem. 2014, 68, 52-61. [CrossRef]

29. Lentz, R.D.; Lehrsch, G.A. Manure and Fertilizer Effects on Carbon Balance and Organic and Inorganic Carbon Losses for an Irrigated Corn Field. Soil Sci. Soc. Am. J. 2014, 78, 987. [CrossRef]

30. Rees, R.M.; Bingham, I.J.; Baddeley, J.A.; Watson, C.A. The role of plants and land management in sequestering soil carbon in temperate arable and grassland ecosystems. Geoderma 2005, 128, 130-154. [CrossRef]

31. Huang, T.; Gao, B.; Christie, P.; Ju, X. Net global warming potential and greenhouse gas intensity in a double-cropping cereal rotation as affected by nitrogen and straw management. Biogeosciences 2013, 10, 7897-7911. [CrossRef]

32. Limin, A.; Shimizu, M.; Mano, M.; Ono, K.; Miyata, A.; Wada, H.; Nozaki, H.; Hatano, R. Manure application has an effect on the carbon budget of a managed grassland in southern Hokkaido, Japan. Soil Sci. Plant Nutr. 2015, 61, 857-872. [CrossRef]

33. Clayton, H.; McTaggart, I.P.; Parker, J.; Swan, L.; Smith, K.A. Nitrous oxide emissions from fertilised grassland: A 2-year study of the effects of $\mathrm{N}$ fertiliser form and environmental conditions. Biol. Fertil. Soils 1997, 25, 252-260. [CrossRef]

34. Shimizu, M.; Hatano, R.; Arita, T. The effect of fertilizer and manure application on $\mathrm{CH}_{4}$ and $\mathrm{N}_{2} \mathrm{O}$ emissions from managed grasslands in Japan. Soil Sci. Plant Nutr. 2013, 59, 69-86. [CrossRef]

35. Acton, S.D.; Baggs, E.M. Interactions between $\mathrm{N}$ application rate, $\mathrm{CH}_{4}$ oxidation and $\mathrm{N}_{2} \mathrm{O}$ production in soil. Biogeochemistry 2011, 103, 15-26. [CrossRef]

36. Robertson, P.G.; Grace, P.R. Greenhouse gas gluxes in tropical and temperate agriculture: The need for a full-cost accounting of global warming potentials. Environ. Dev. Sustain. 2004, 6, 51-63. [CrossRef]

37. Zheng, X.; Xie, B.; Liu, C.; Zhou, Z.; Yao, Z.; Wang, Y.; Wang, Y.; Yang, L.; Zhu, J.; Huang, Y.; et al. Quantifying net ecosystem carbon dioxide exchange of a short-plant cropland with intermittent chamber measurements. Glob. Biogeochem. Cycles 2008, 22, 1-13. [CrossRef]

38. Chapin, F.S.; Woodwell, G.M.; Randerson, J.T.; Rastetter, E.B.; Lovett, G.M.; Baldocchi, D.D.; Clark, D.A.; Harmon, M.E.; Schimel, D.S.; Valentini, R.; et al. Reconciling carbon-cycle concepts, terminology, and methods. Ecosystems 2006, 9, 1041-1050. [CrossRef]

39. Yang, B.; Xiong, Z.; Wang, J.; Xu, X.; Huang, Q.; Shen, Q. Mitigating net global warming potential and greenhouse gas intensities by substituting chemical nitrogen fertilizers with organic fertilization strategies in rice-wheat annual rotation systems in China: A 3-year fi eld experiment. Ecol. Eng. 2015, 81, $289-297$. [CrossRef]

40. Mosier, A.R.; Halvorson, A.D.; Reule, C.A.; Liu, X.J. Net Global Warming Potential and Greenhouse Gas Intensity in Irrigated Cropping Systems in Northeastern Colorado. J. Environ. Qual. 2006, 35, 1584-1598. [CrossRef] [PubMed]

41. Ni, K.; Ding, W.; Zaman, M.; Cai, Z.; Wang, Y.; Zhang, X.; Zhou, B. Nitrous oxide emissions from a rainfed-cultivated black soil in Northeast China: Effect of fertilization and maize crop. Biol. Fertil. Soils 2012, 48, 973-979. [CrossRef]

42. Roth, B.; Jones, M.; Burke, J.; Williams, M. The Effects of Land-Use Change from Grassland to Miscanthus $x$ giganteus on Soil $\mathrm{N}_{2} \mathrm{O}$ Emissions. Land 2013, 2, 437-451. [CrossRef]

43. Shimizu, M.; Marutani, S.; Desyatkin, A.R.; Jin, T.; Hata, H.; Hatano, R. The effect of manure application on carbon dynamics and budgets in a managed grassland of Southern Hokkaido, Japan. Agric. Ecosyst. Environ. 2009, 130, 31-40. [CrossRef]

44. Bhattacharyya, P.; Roy, K.S.; Neogi, S.; Adhya, T.K.; Rao, K.S.; Manna, M.C. Effects of rice straw and nitrogen fertilization on greenhouse gas emissions and carbon storage in tropical flooded soil planted with rice. Soil Tillage Res. 2012, 124, 119-130. [CrossRef]

45. Toma, Y.; Hatano, R. Effect of crop residue C:N ratio on $\mathrm{N}_{2} \mathrm{O}$ emissions from Gray Lowland soil in Mikasa, Hokkaido, Japan: Original article. Soil Sci. Plant Nutr. 2007, 53, 198-205. [CrossRef] 
46. Shimizu, M.; Limin, A.; Desyatkin, A.R.; Jin, T.; Mano, M.; Ono, K.; Miyata, A.; Hata, H.; Hatano, R. Effect of manure application on seasonal carbon fluxes in a temperate managed grassland in Southern Hokkaido, Japan. Catena 2015, 133, 474-485. [CrossRef]

47. Katayanagi, N.; Ryusuke, $\mathrm{H} . \mathrm{N}_{2} \mathrm{O}$ emissions during the freezing and thawing periods from six fields in a livestock farm, southern Hokkaido, Japan. Soil Sci. Plant Nutr. 2012, 58, 261-271. [CrossRef]

48. Ussiri, D.A.N.; Lal, R.; Jarecki, M.K. Nitrous oxide and methane emissions from long-term tillage under a continuous corn cropping system in Ohio. Soil Tillage Res. 2009, 104, 247-255. [CrossRef]

49. Cui, F.; Zheng, X.; Liu, C.; Wang, K.; Zhou, Z.; Deng, J. Assessing biogeochemical effects and best management practice for a wheat-maize cropping system using the DNDC model. Biogeosciences 2014, 11, 91-107. [CrossRef]

50. Collins, H.P.; Alva, A.K.; Streubel, J.D.; Fransen, S.F.; Frear, C.; Chen, S.; Kruger, C.; Granatstein, D. Greenhouse Gas Emissions from an Irrigated Silt Loam Soil Amended with Anaerobically Digested Dairy Manure. Soil Sci. Soc. Am. J. 2011, 75, 2206. [CrossRef]

51. Sistani, K.R.; Jn-Baptiste, M.; Lovanh, N.; Cook, K.L. Atmospheric emissions of nitrous oxide, methane, and carbon dioxide from different nitrogen fertilizers. J. Environ. Qual. 2011, 40, 1797-1805. [CrossRef] [PubMed]

52. Saggar, S.; Jha, N.; Deslippe, J.; Bolan, N.S.; Luo, J.; Giltrap, D.L.; Kim, D.G.; Zaman, M.; Tillman, R.W. Denitrification and $\mathrm{N}_{2} \mathrm{O}: \mathrm{N}_{2}$ production in temperate grasslands: Processes, measurements, modelling and mitigating negative impacts. Sci. Total Environ. 2013, 465, 173-195. [CrossRef] [PubMed]

53. Li, M.; Shimizu, M.; Hatano, R. Evaluation of $\mathrm{N}_{2} \mathrm{O}$ and $\mathrm{CO}_{2}$ hot moments in managed grassland and cornfield, southern Hokkaido, Japan. Catena 2015, 133, 1-13. [CrossRef]

54. Ding, W.; Cai, Y.; Cai, Z.; Yagi, K.; Zheng, X. Nitrous oxide emissions from an intensively cultivated maize-wheat rotation soil in the North China Plain. Sci. Total Environ. 2007, 373, 501-511. [CrossRef] [PubMed]

55. Ranucci, S.; Bertolini, T.; Vitale, L.; Tommasi, P.; Ottaiano, L.; Oliva, M.; Amato, U.; Fierro, A.; Magliulo, V. The influence of management and environmental variables on soil $\mathrm{N}_{2} \mathrm{O}$ emissions in a crop system in Southern Italy. Plant Soil 2010, 343, 83-96. [CrossRef]

56. Cai, Y.; Ding, W.; Luo, J. Nitrous oxide emissions from Chinese maize-wheat rotation systems: A 3-year field measurement. Atmos. Environ. 2013, 65, 112-122. [CrossRef]

57. Harty, M.A.; Forrestal, P.J.; Watson, C.J.; McGeough, K.L.; Carolan, R.; Elliot, C.; Krol, D.; Laughlin, R.J.; Richards, K.G.; Lanigan, G.J. Reducing nitrous oxide emissions by changing N fertiliser use from calcium ammonium nitrate (CAN) to urea based formulations. Sci. Total Environ. 2016, 563-564, 576-586. [CrossRef] [PubMed]

58. Flessa, $\mathrm{H}$. Seasonal variation of $\mathrm{N}_{2} \mathrm{O}$ and $\mathrm{CH}_{4}$ fluxes in differently managed arable soils in southern Germany. J. Geophys. Res. 1995, 100, 115-124. [CrossRef]

59. MacKenzie, A.F.; Fan, M.X.; Cadrin, F. Nitrous oxide emission as affected by tillage, corn-soybean-alfalfa rotations and nitrogen fertilization. Can. J. Soil Sci. 1997, 77, 145-152. [CrossRef]

60. Collins, H.P.; Streubel, J.D.; Frear, C.; Chen, S.; Granatstein, D.; Kruger, C.; Alva, A.K.; Fransen, S.F. Application of AD Dairy Manure Effluent to Fields and Associated Impacts; Center for Sustaining Agriculture and Natural Resources: Leavenworth, WA, USA, 2010; pp. 1-25.

61. Akiyama, H.; McTaggart, I.P.; Ball, B.C.; Scott, A. $\mathrm{N}_{2} \mathrm{O}, \mathrm{NO}$, and $\mathrm{NH}_{3}$ emissions from soil after the application of organic fertilizers, urea and water. Water Air Soil Pollut. 2004, 156, 113-129. [CrossRef]

62. Whalen, J.K.; Chang, C.; Clayton, G.W.; Carefoot, J.P. Cattle Manure Amendments Can Increase the pH of Acid Soils. Soil Sci. Soc. Am. J. 2000, 64, 962-966. [CrossRef]

63. Nagano, H.; Kato, S.; Ohkubo, S.; Inubushi, K. Emmisions of carbon dioxide, methane, and nitrous oxide from short and long-term organic farming Andosols in central Japan. Jpn. Soc. Soil Sci. Plant Nutr. J. 2012, 58, 793-801. [CrossRef]

64. Owen, J.J.; Parton, W.J.; Silver, W.L. Long-term impacts of manure amendments on carbon and greenhouse gas dynamics of rangelands. Glob. Chang. Biol. 2015, 21, 4533-4547. [CrossRef] [PubMed]

65. Ussiri, D.A.N.; Lal, R. Long-term tillage effects on soil carbon storage and carbon dioxide emissions in continuous corn cropping system from an alfisol in Ohio. Soil Tillage Res. 2009, 104, 39-47. [CrossRef]

66. Hu, Z.; Zhang, J.; Li, S.; Xie, H. Impact of carbon source on nitrous oxide emission from anoxic/oxic biological nitrogen removal process and identification of its emission sources. Environ. Sci. Pollut. Res. 2013, 20, 1059-1069. [CrossRef] [PubMed] 
67. Cabrera, M.L.; Chiang, S.C.; Merka, W.C.; Pancorbo, O.C.; Thompson, S.A. Nitrous oxide and carbon dioxide emissions from pelletized and nonpelletized poultry litter incorporated into soil. Plant Soil 1994, 163, $189-195$. [CrossRef]

68. Ryals, R.; Silver, W.L. Effects of organic matter amendments on net primary productivity and greenhouse gas emissions in annual grasslands. Ecol. Appl. 2012, 23, 46-59. [CrossRef]

69. Choudhary, M.A.; Akramkhanov, A.; Saggar, S. Nitrous oxide emissions in soils cropped with maize under long-term tillage and under permanent pasture in New Zealand. Soil Tillage Res. 2001, 62, 61-71. [CrossRef]

70. Mosier, A.; Schime, D.; Valentine, D.; Bronson, K.; Parton, W. Methane and nitrous oxide fluxes in native, fertilized and cultivated grasslands. Nature 1991, 350, 56-58. [CrossRef]

71. Sehy, U.; Ruser, R.; Munch, J.C. Nitrous oxide fluxes from maize fields: Relationship to yield, site-specific fertilization, and soil conditions. Agric. Ecosyst. Environ. 2003, 99, 97-111. [CrossRef]

72. Clough, T.J.; Kelliher, F.M.; Sherlock, R.R.; Ford, C.D. Lime and Soil Moisture Effects on Nitrous Oxide Emissions from a Urine Patch. Soil Sci. Soc. Am. J. 2004, 68, 1600-1609. [CrossRef]

73. Pan, Y.; Ye, L.; Yuan, Z. Effect of $\mathrm{H}_{2} \mathrm{~S}$ on $\mathrm{N}_{2} \mathrm{O}$ reduction and accumulation during denitrification by methanol utilizing denitrifiers. Environ. Sci. Technol. 2013, 47, 8408-8415. [CrossRef] [PubMed]

74. Wu, X.; Yao, Z.; Brüggemann, N.; Shen, Z.Y.; Wolf, B.; Dannenmann, M.; Zheng, X.; Butterbach-Bahl, K. Effects of soil moisture and temperature on $\mathrm{CO}_{2}$ and $\mathrm{CH}_{4}$ soil-atmosphere exchange of various land use/cover types in a semi-arid grassland in Inner Mongolia, China. Soil Biol. Biochem. 2010, 42, 773-787. [CrossRef]

75. Wang, Y.Y.; Hu, C.S.; Ming, H.; Zhang, Y.M.; Li, X.X.; Dong, W.X.; Oenema, O. Concentration profiles of $\mathrm{CH}_{4}$, $\mathrm{CO}_{2}$ and $\mathrm{N}_{2} \mathrm{O}$ in soils of a wheat-maize rotation ecosystem in North China Plain, measured weekly over a whole year. Agric. Ecosyst. Environ. 2013, 164, 260-272. [CrossRef]

76. Wang, Y.; Hu, C.; Ming, H.; Oenema, O.; Schaefer, D.A.; Dong, W.; Zhang, Y.; Li, X. Methane, Carbon Dioxide and Nitrous Oxide Fluxes in Soil Profile under a Winter Wheat-Summer Maize Rotation in the North China Plain. PLoS ONE 2014, 9, e98445. [CrossRef] [PubMed]

77. Guo, J.; Zhou, C. Greenhouse gas emissions and mitigation measures in Chinese agroecosystems. Agric. For. Meteorol. 2007, 142, 270-277. [CrossRef]

78. Phillips, R.L.; Wick, A.F.; Liebig, M.A.; West, M.S.; Daniels, W.L. Biogenic emissions of $\mathrm{CO}_{2}$ and $\mathrm{N}_{2} \mathrm{O}$ at multiple depths increase exponentially during a simulated soil thaw for a northern prairie Mollisol. Soil Biol. Biochem. 2012, 45, 14-22. [CrossRef]

79. Zhang, X.-B.; Wu, L.-H.; Sun, N.; Ding, X.-S.; Li, J.-W.; Wang, B.-R.; Li, D.-C. Soil $\mathrm{CO}_{2}$ and $\mathrm{N}_{2} \mathrm{O}$ Emissions in Maize Growing Season Under Different Fertilizer Regimes in an Upland Red Soil Region of South China. J. Integr. Agric. 2014, 13, 604-614. [CrossRef]

80. Bond-lamberty, B.; Smith, A.P.; Bailey, V. Temperature and moisture effects on greenhouse gas emissions from deep active-layer boreal soils. Biogeosciences 2016, 13, 6669-6681. [CrossRef]

81. Ding, W.; Cai, Y.; Cai, Z.; Yagi, K.; Zheng, X. Soil Respiration under Maize Crops: Effects of Water, Temperature, and Nitrogen Fertilization. Soil Sci. Soc. Am. J. 2007, 71, 944. [CrossRef]

82. Zhou, L.; Zhou, X.; Zhang, B.; Lu, M.; Luo, Y.; Liu, L.; Li, B. Different responses of soil respiration and its components to nitrogen addition among biomes: A meta-analysis. Glob. Chang. Biol. 2014, 20, 2332-2343. [CrossRef] [PubMed]

83. Chen, H.; Tian, H.Q. Does a general temperature-dependent Q10 model of soil respiration exist at biome and global scale? J. Integr. Plant Biol. 2005, 47, 1288-1302. [CrossRef]

84. Peng, S.; Piao, S.; Wang, T.; Sun, J.; Shen, Z. Temperature sensitivity of soil respiration in different ecosystems in China. Soil Biol. Biochem. 2009, 41, 1008-1014. [CrossRef]

85. Liu, H.S.; Li, L.H.; Han, X.G.; Huang, J.H.; Sun, J.X.; Wang, H.Y. Respiratory substrate availability plays a crucial role in the response of soil respiration to environmental factors. Appl. Soil Ecol. 2006, 29, 284-293. [CrossRef]

86. Zhai, L.-M.; Liu, H.-B.; Zhang, J.-Z.; Huang, J.; Wang, B.-R. Long-Term Application of Organic Manure and Mineral Fertilizer on $\mathrm{N}_{2} \mathrm{O}$ and $\mathrm{CO}_{2}$ Emissions in a Red Soil from Cultivated Maize-Wheat Rotation in China. Agric. Sci. China 2011, 10, 1748-1757. [CrossRef]

87. Anthoni, P.M.; Freibauer, A.; Kolle, O.; Schulze, E.D. Winter wheat carbon exchange in Thuringia, Germany. Agric. For. Meteorol. 2004, 121, 55-67. [CrossRef] 
88. West, T.O.; Marland, G. A synthesis of carbon sequestration, carbon emissions, and net carbon flux in agriculture: Comparing tillage practices in the United States. Agric. Ecosyst. Environ. 2002, 91, 217-232. [CrossRef]

89. Lal, R. Soil carbon sequestration to mitigate climate change. Geoderma 2004, 123, 1-22. [CrossRef]

90. Yan, G.; Zheng, X.; Cui, F.; Yao, Z.; Zhou, Z. Two-year simultaneous records of $\mathrm{N}_{2} \mathrm{O}$ and NO fluxes from a farmed cropland in the northern China plain with a reduced nitrogen addition rate by one-third. Agric. Ecosyst. Environ. 2013, 178, 39-50. [CrossRef]

(c) (C) 2017 by the authors; licensee MDPI, Basel, Switzerland. This article is an open access article distributed under the terms and conditions of the Creative Commons Attribution (CC BY) license (http:/ / creativecommons.org/licenses/by/4.0/). 